Article

\title{
Encapsulation of a nickel Salen complex in nanozeolite LTA as a carbon paste electrode modifier for electrocatalytic oxidation of hydrazine
}

\author{
Seyed Karim Hassaninejad-Darzi * \\ Department of Chemistry, Faculty of Basic Science, Babol Noshirvani University of Technology, Shariati Ave., Babol 47148-71167, Iran
}

\section{A R T I C L E I N F}

\section{Article history:}

Received 26 September 2017

Accepted 14 January 2018

Published 5 February 2018

\section{Keywords:}

Nanozeolite linde type A

Salen complex

Ni(II)-SalenA modified carbon

paste electron

Hydrazine

Electrocatalytic oxidation

Fuel cell

\begin{abstract}
A B S T R A C T
A nickel salen complex was encapsulated in the supercages of nanozeolite NaA, LTA (linde type A) structure, using the flexible ligand method. The electrochemical behavior and electrocatalytic activity of a carbon paste electrode (CPE) modified with Ni(II)-Salen-A (Ni(II)-SalenA/CPE) for hydrazine oxidation in $0.1 \mathrm{~mol} / \mathrm{L} \mathrm{NaOH}$ solution were investigated by cyclic voltammetry, chronoamperometry, and chronocoulometry. First, organic-template-free synthesis of nanozeolite LTA was performed and the obtained material was characterized by various techniques. The average particle size of the LTA crystals was estimated to be 56.1 and $72 \mathrm{~nm}$ by X-ray diffraction and particle size analysis, respectively. The electron transfer coefficient was found to be 0.64 and the catalytic rate constant for oxidation of hydrazine at the redox sites of Ni(II)-SalenA/CPE was found to be $1.03 \times$ $10^{5} \mathrm{~cm}^{3} /(\mathrm{mol} \cdot \mathrm{s})$. Investigation of the electrocatalytic mechanism suggested that oxidation of hydrazine occurred through reaction with $\mathrm{Ni}^{3+}($ Salen $) \mathrm{O}(\mathrm{OH})$ and also direct electrooxidation. The anodic peak currents revealed a linear dependence on the square root of the scan rate, indicating a diffusion-controlled process, and the diffusion coefficient of hydrazine was found to be $1.18 \times 10^{-7} \mathrm{~cm}^{2} / \mathrm{s}$. The results indicated that Ni(II)-SalenA/CPE displays good electrocatalytic activity toward hydrazine oxidation owing to the porous structure of nanozeolite LTA and the Ni(II)-Salen complex. Finally, the general reaction mechanism for the electrooxidation of hydrazine on Ni(II)-SalenA/CPE in alkaline solution involves the transfer of four electrons, in which the first electron transfer reaction acts as the rate-limiting step followed by a three-electron process to generate environmentally friendly nitrogen and water as final products.
\end{abstract}

(C) 2018, Dalian Institute of Chemical Physics, Chinese Academy of Sciences. Published by Elsevier B.V. All rights reserved.

\section{Introduction}

Hydrazine $\left(\mathrm{N}_{2} \mathrm{H}_{4}\right)$ is a small and reactive molecule with powerful reducing capabilities that can undergo diverse reactions in numerous applications. In addition, it is widely used in various fields, including fuel cells, catalysts, and industrial, agricultural, military, pharmacological, and aerospace applications [1,2]. Further, $\mathrm{N}_{2} \mathrm{H}_{4}$ is an important chemical of environmental and pharmaceutical interest, and reported to be a neu- rotoxin that produces carcinogenic and mutagenic effects [3]. Despite the wide application of $\mathrm{N}_{2} \mathrm{H}_{4}$ in various fields, it has been recognized to be unsafe for humans and therefore, sensitive and fast methods for the detection and determination of $\mathrm{N}_{2} \mathrm{H}_{4}$ in low concentrations in various media are becoming more significant $[2,4]$. $\mathrm{N}_{2} \mathrm{H}_{4}$ is an important high-performance fuel in aerospace propulsion applications, and also has promising potential applications in fuel cells. In fact, $\mathrm{N}_{2} \mathrm{H}_{4}$ may be an ideal fuel for direct fuel cell systems because the absence of

\footnotetext{
*Corresponding author. Tel: +98-1132332071-1735; Fax: +98-1132334203; E-mail: hassaninejad@nit.ac.ir

DOI: 10.1016/S1872-2067(18)63025-6 | http://www.sciencedirect.com/science/journal/18722067 | Chin. J. Catal., Vol. 39, No. 2, February 2018
} 
carbon atoms in $\mathrm{N}_{2} \mathrm{H}_{4}$ leads to zero production of species that may poison the electrocatalyst and reduces the overall emission of $\mathrm{CO}_{2}$ as a greenhouse gas [2]. The direct hydrazine fuel cell (DHFC) exhibits an electromotive force of $1.56 \mathrm{~V}$ vs. standard hydrogen electrode (SHE), which is higher than that for other fuel cells using hydrogen $(1.24 \mathrm{~V}$ ) or methanol $(1.19 \mathrm{~V})$ as a fuel [5]. In addition, the decomposition products of $\mathrm{N}_{2} \mathrm{H}_{4}$, nitrogen and water, are ecologically friendly.

The electrooxidation of $\mathrm{N}_{2} \mathrm{H}_{4}$ is connected with the technological development of DHFCs. Various materials have been investigated for the electrooxidation of $\mathrm{N}_{2} \mathrm{H}_{4}$, including Pt nanoparticles [1], Au-SH-SiO $/$ MOF [2], $\mathrm{Au}$ electrodes [6], CuNPs-PANI-Nano-ZSM-5 [7], Pd modified multi-walled carbon nanotubes (MWCNTs) [8], nano-Ni-MWNTs-textile electrodes [9], nickel ternary alloys at graphite electrodes [10], nanoporous $\mathrm{NiCuP}$ amorphous alloys [11], $\mathrm{NiO}_{x}-\mathrm{Pt} / \mathrm{C}$ [12], $\mathrm{CuO} / \mathrm{NiO}$ composite nanofibers [13], modified MWCNTs [14], and modified carbon paste electrodes (CPEs) [15-17].

Zeolites are crystalline aluminosilicate composites of $\mathrm{Si}, \mathrm{Al}$, and $\mathrm{O}$ with a structure of linked tetrahedra, each consisting of four $\mathrm{O}$ atoms surrounding a cation; the structure contains a network of channels and cages [18]. One of the most representative artificial aluminosilicate zeolites, zeolite NaA (LTA), was first synthesized by a hydrothermal crystallization method and has been utilized industrially in catalysts, adsorbents, ion exchangers, and zeolite membranes $[19,20]$. This material is a microporous crystalline aluminosilicate zeolite that has a channel opening size of $0.4 \mathrm{~nm}$ and a cubic structure of three-dimensional pores $[19,21]$. The preparation of zeolite-modified electrodes (ZMEs) is fast, easy, and cheap [22]. The next challenge is to prepare ZMEs on a carbon substrate for cyclic voltammetry (CV) because the prepared catalysts have to be loaded on a substrate to act as a stable solid electrode [22].

It is important to develop a novel electrode that has high sensitivity and stability for the electrooxidation of $\mathrm{N}_{2} \mathrm{H}_{4}$. Some studies have been performed on the synthesis of metal Salen $\left(N, N^{\prime}\right.$-bis(salicylidene)ethylenediamine) complexes immobilized on zeolites as active catalysts for organic reactions $[23,24]$. Most studies have focused on the encapsulation of metal salen complexes in zeolitic hosts for the electrocatalytic oxidation of methanol in alkaline solution [25-28]. There are no literature reports on the application of CPEs modified with nickel(II) salen complexes encapsulated in nanozeolite LTA for the electrocatalytic oxidation of $\mathrm{N}_{2} \mathrm{H}_{4}$. Hence, the synthesis of nanozeolite LTA without an organic template was performed and the obtained material was characterized by various techniques. Then, a CPE was modified with a nanozeolite LTA-encapsulated Ni(II)Salen complex (Ni(II)-SalenA/CPE) and its electrocatalytic performance for $\mathrm{N}_{2} \mathrm{H}_{4}$ oxidation was evaluated in alkaline solution. The reaction mechanism of $\mathrm{N}_{2} \mathrm{H}_{4}$ oxidation on the modified electrode was further considered using $\mathrm{CV}$, chronoamperometry, and chronocoulometry.

\section{Experimental}

\subsection{Reagents and materials}

All chemicals were analytical grade and used without any further purification. $\mathrm{NaOH}$, tetraethyl orthosilicate (TEOS), $\mathrm{N}_{2} \mathrm{H}_{4}, \mathrm{Ni}\left(\mathrm{CH}_{3} \mathrm{COO}\right)_{2}$, ethylenediamine, salicylaldehyde, $\mathrm{KCl}$, $\mathrm{K}_{3} \mathrm{Fe}(\mathrm{CN})_{6}$, and $\mathrm{K}_{4} \mathrm{Fe}(\mathrm{CN})_{6}$ were purchased from Merck. Diethyl ether ( $99 \mathrm{wt} \%$ ) and sodium aluminate were purchased from Daejung Company. Graphite powder and paraffin oil $(d=0.88$ $\mathrm{g} / \mathrm{cm}^{3}$ ) as the binding agent (both from Daejung Company) were used for preparing the pastes. Deionized water was used throughout the experiments.

\subsection{Synthesis of organic-template-free nanozeolite NaA}

The synthesis procedure for nanometer-sized zeolite NaA has been described elsewhere [29]. Aluminosilicate gel was prepared by mixing a freshly prepared aluminate solution with a silicate solution at a molar ratio of $1.0 \quad \mathrm{Al}_{2} \mathrm{O}_{3}: 4.0 \quad \mathrm{SiO}_{2}: 5.5$ $\mathrm{Na}_{2} \mathrm{O}: 190 \mathrm{H}_{2} \mathrm{O}$. First, a $300 \mathrm{~mL}$ plastic bottle containing a freshly prepared sodium aluminate solution (17.46 $\mathrm{g}$ of $\mathrm{NaOH}, 180$ $\mathrm{mL}$ of $\mathrm{H}_{2} \mathrm{O}$, and $10.52 \mathrm{~g}$ of $\mathrm{NaAlO}_{2}$ ) and a stirring bar was immersed in an ice-water bath. The mixture was cooled for $1 \mathrm{~h}$ with stirring and then $47.13 \mathrm{~mL}$ of TEOS was added. The hydrolysis of TEOS was controlled at $0{ }^{\circ} \mathrm{C}$ in order to obtain a nanometer-sized aluminosilicate gel. Stirring was continued at $0{ }^{\circ} \mathrm{C}$ for $6 \mathrm{~h}$ and then at room temperature for another $24 \mathrm{~h}$. Hydrothermal crystallization was performed at $60{ }^{\circ} \mathrm{C}$ for $48 \mathrm{~h}$ in a shaker with a rotation rate of $250 \mathrm{r} / \mathrm{min}$. The powdered products were recovered by repeated high-speed centrifugation at $12000 \mathrm{r} / \mathrm{min}$ and washing with deionized water until $\mathrm{pH}$ $<8$, followed by drying at room temperature for $24 \mathrm{~h}$.

\subsection{Preparation and characterization of the Ni(II)-SalenA}

To prepare Ni(II)A using the ion-exchange method, $2 \mathrm{~g}$ of nanozeolite $\mathrm{NaA}$ was suspended in $50 \mathrm{~mL}$ of $\mathrm{Ni}\left(\mathrm{CH}_{3} \mathrm{COO}\right)_{2}$ aqueous solution $(0.01 \mathrm{~mol} / \mathrm{L})$, and the mixture was stirred for $24 \mathrm{~h}$ at ambient temperature. Then, the solid fraction was filtered, washed three times with deionized water, and dried at $100{ }^{\circ} \mathrm{C}$ for $12 \mathrm{~h}$ to obtain Ni(II)A [30]. The metal complex was encapsulated in the structure of nanozeolite $\mathrm{NaA}$ by using the flexible ligand method [31]. First, Ni(II)A was mixed with excessive amounts of $\mathrm{H}_{2}$ Salen ( $n_{\text {ligand }} / n_{\text {metal }}=3$ ) in a crucible with a cover. The complexation was performed at $170{ }^{\circ} \mathrm{C}$ for $24 \mathrm{~h}$ under high vacuum conditions. The molten slurry was cooled to room temperature and extracted with acetone by Soxhlet extraction until the solvent was colorless in order to remove uncomplexed ligands and complex molecules adsorbed on the exterior surface. The extracted sample was then ion-exchanged with a $\mathrm{NaCl}$ aqueous solution $(0.1 \mathrm{~mol} / \mathrm{L})$ to remove uncoordinated $\mathrm{Ni}^{2+}$, followed by washing with deionized water until no chloride ions were detected with a $\mathrm{AgNO}_{3}$ aqueous solution to obtain Ni(II)-SalenA.

\subsection{Apparatus and characterization}

Powder X-ray diffraction (XRD) patterns were recorded using a X-ray diffractometer (MPD 3000 Instrument) with Be-filtered $\mathrm{Cu} K_{\alpha}$ radiation $(\lambda=1.5418 \AA$ ) operating at $35.4 \mathrm{kV}$ 
and $28 \mathrm{~mA}$. A Perkin Elmer Fourier transform infrared (FT-IR) spectrometer was utilized to record FT-IR spectra at room temperature. Field emission scanning electron microscopy (FESEM) and energy dispersive spectroscopy (EDS) were performed to determine the crystallite size, morphology, and elemental composition of the synthesized sample using a Mira-3 XMU instrument. The particle size distribution of the synthesized sample was determined using a laser particle sizer (Analysette 22 NanoTec Plus, Fritsch $\mathrm{GmbH}$ ) to investigate the solid material suspended in distilled water. Measurements of nitrogen adsorption/desorption at the temperature of liquid nitrogen were carried out using volumetric adsorption equipment (Micromeritics ASAP 2020). The specific surface area $\left(S_{\mathrm{BET}}\right)$ of the samples was estimated by the Brunauer-Emmett-Teller (BET) method [32]. The electrochemical experiments were performed using a potentiostat/galvanostat (SAMA500 electroanalyzer system) with a voltammetry cell in a three-electrode configuration. $\mathrm{Ag}|\mathrm{AgCl}| \mathrm{KCl}(3 \mathrm{~mol} / \mathrm{L})$ and platinum wire (both from Azar Electrode Company) were used as reference and auxiliary electrodes, respectively. A homemade bare CPE and modified CPEs (Salen/CPE, NaA/CPE, $\mathrm{Ni}(\mathrm{II}) \mathrm{A} / \mathrm{CPE}$, and $\mathrm{Ni}(\mathrm{II})$-SalenA/CPE) were used as working electrodes in the electrochemical experiments.

\subsection{Electrode preparation}

Typically, to prepare Ni(II)-SalenA/CPE (15 wt\%), $30 \mathrm{mg}$ of $\mathrm{Ni}(\mathrm{II})$-SalenA and $170 \mathrm{mg}$ of graphite powder were thoroughly mixed with diethyl ether. After evaporation of the solvent, two drops of paraffin oil (35 wt\%) were added and blended in a mortar by hand mixing for 30 min until a uniformly wetted paste was obtained. The resulting paste was packed into the end of a glass tube ( $4.0 \mathrm{~mm}$ inner diameter and $10 \mathrm{~cm}$ length) with a copper wire as an electrical contact. A new surface was obtained by pushing excess paste out of the tube and polishing with weighing paper. For comparison, the bare CPE was prepared in the same way without adding $\mathrm{Ni}(\mathrm{II})$-SalenA, and Salen/CPE, NaA/CPE, and Ni(II)A/CPE were fabricated by adding $\mathrm{H}_{2}$ Salen, $\mathrm{NaA}$, and $\mathrm{Ni}(\mathrm{II}) \mathrm{A}$, respectively. All currents $(I)$ and charges $(Q)$ were converted to current densities by dividing $I$ or $Q$ by the geometric area $\left(0.12566 \mathrm{~cm}^{2}\right)$.

\section{Results and discussion}

\subsection{Characterization of nanozeolite NaA and Ni(II)-SalenA}

XRD pattern of the synthesized nanozeolite is presented in Fig. 1(a). The crystallization products matched the characteristic peaks of zeolite $\mathrm{NaA}$ with good crystallinity $[27,29]$. The main peaks are observed at $2 \theta=7.2^{\circ}, 10.3^{\circ}, 12.6^{\circ}, 16.2^{\circ}, 21.8^{\circ}$, $24.0^{\circ}, 26.2^{\circ}, 27.2^{\circ}, 30.0^{\circ}, 30.9^{\circ}, 31.0^{\circ}$, and $34.2^{\circ}$, which confirm the synthesis of pure-phase NaA nanozeolite $[29,33]$. The crystalline size of the synthesized sample was calculated using the Scherrer equation [34]:

$$
d=\frac{0.89 \lambda}{\beta \operatorname{Cos} \theta}
$$

where $d$ is the crystalline size, $\lambda$ is the wavelength of the X-ray source used in XRD $(0.15418 \mathrm{~nm}), \beta$ is the breadth of the observed diffraction line at its half-intensity maximum in radian, and $\theta$ is the angle of the main Bragg peak. From the diffraction
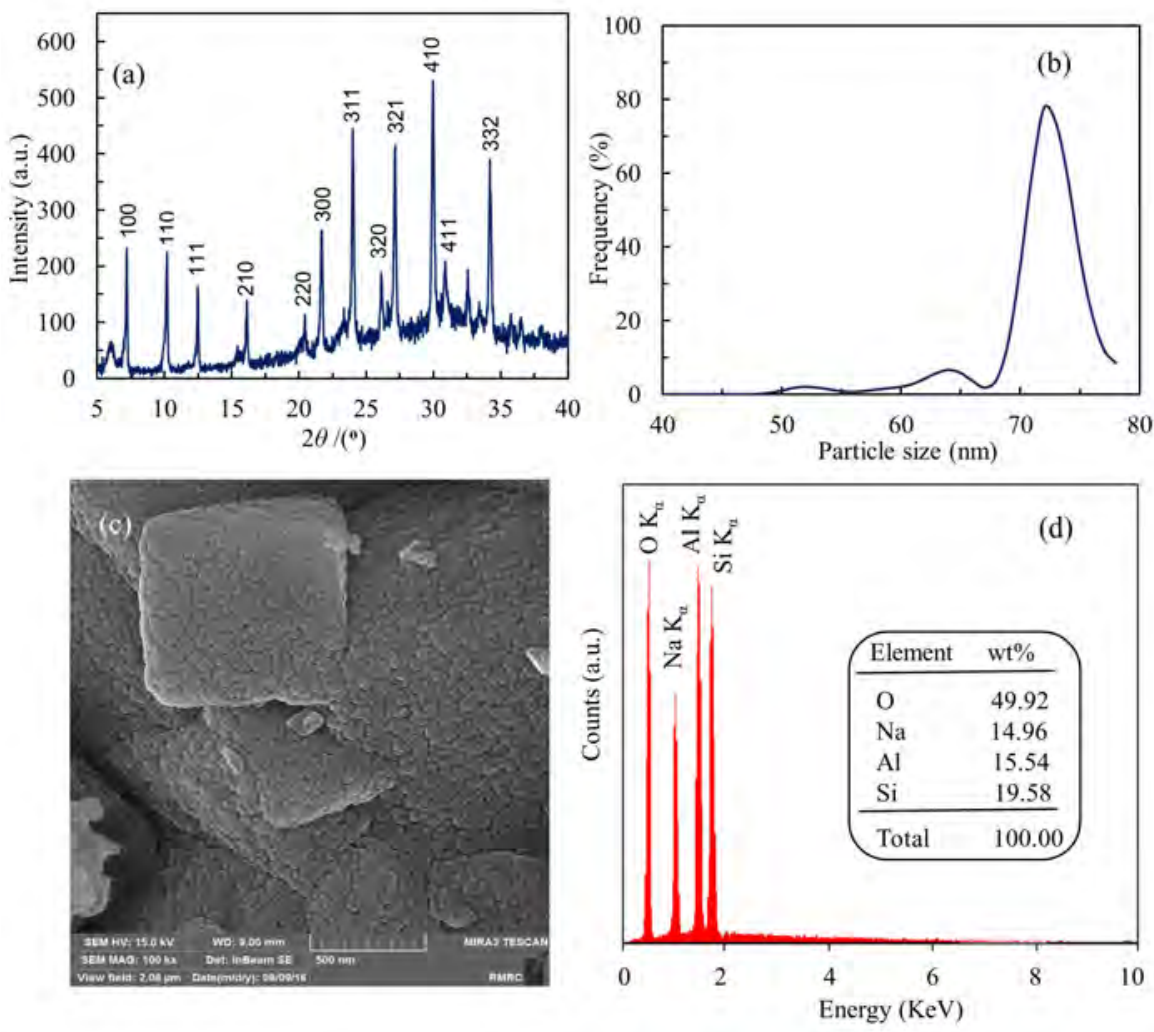

Fig. 1. Representative XRD pattern (a), particle size analysis (b), FESEM image (c), and EDS spectrum (d) of nanozeolite NaA. 
peaks at $2 \theta=7.2^{\circ}, 24^{\circ}, 27^{\circ}, 30^{\circ}$, and $34^{\circ}$ the average particle size of the synthesized sample obtained using the Scherrer equation was $56.1 \mathrm{~nm}$. It is apparent that the diffraction lines are significantly broadened, which may indicate a smaller crystallite size.

Fig. 1(b) displays a particle size analysis (PSA) graph for nanozeolite $\mathrm{NaA}$ according to the Mie theory. The average particle sizes of nanozeolite $\mathrm{NaA}$ are between 67 and $78 \mathrm{~nm}$ and the mean particle size is about $72 \mathrm{~nm}$, corresponding to a cumulative volume frequency of $78 \%$. Fig. 1(c) shows a FESEM image of the synthesized nanoparticles, which indicates that semispherical nanozeolite NaA particles were formed with an average particle size of less than $100 \mathrm{~nm}$. These results confirmed that the size distribution obtained by PSA is in agreement with the results from XRD analysis and FESEM. In addition, Fig. 1(d) presents an EDS spectrum of the prepared nanozeolite, which confirms the presence of $\mathrm{O}, \mathrm{Na}, \mathrm{Al}$, and $\mathrm{Si}$ in the synthesized sample.

Fig. 2 shows FT-IR spectra of nanozeolite Ni(II)A and $\mathrm{Ni}(\mathrm{II})$ SalenA in the wavenumber range of $450-2800 \mathrm{~cm}^{-1}$. A strong wide vibration peak was observed at $830-1300 \mathrm{~cm}^{-1}$ (centered at $990 \mathrm{~cm}^{-1}$ ) for nanozeolite $\mathrm{Ni}(\mathrm{II}) \mathrm{A}$, which can reasonably be assigned to $\mathrm{T}-\mathrm{O}(\mathrm{T}=\mathrm{Si}$ or $\mathrm{Al})$ stretching modes and may overlap with Al-O-Si stretching vibrations [35]. The bands located at 463,551 , and $671 \mathrm{~cm}^{-1}$ are ascribed to Si-O-Al bending vibrations, vibrations of external linkages of double six-member rings, and symmetric stretching of internal tetrahedra, respectively [35,36]. The band at about $1660 \mathrm{~cm}^{-1}$ is attributed to the bending vibration of water molecules adsorbed on hydroxyl groups [20]. Bands in the range of $1200-1600 \mathrm{~cm}^{-1}$, ascribed to aromatic ring and $\mathrm{C}=\mathrm{N}$ vibrations of the salen ligand, are clearly observed in the IR spectrum of the Ni(II) SalenA sample [37]. However, these bands of the encapsulated complex were very weak owing to the low concentration in the zeolite cages. In contrast, these bands are absent in the FT-IR spectrum of Ni(II)A. The ligand vibration bands in the other regions are obscured by the presence of zeolitic vibration bands [27]. This observation provides effective evidence for the presence of nickel complexes inside the cavities of nanozeolite $\mathrm{NaA}$ in the Ni(II)SalenA sample.

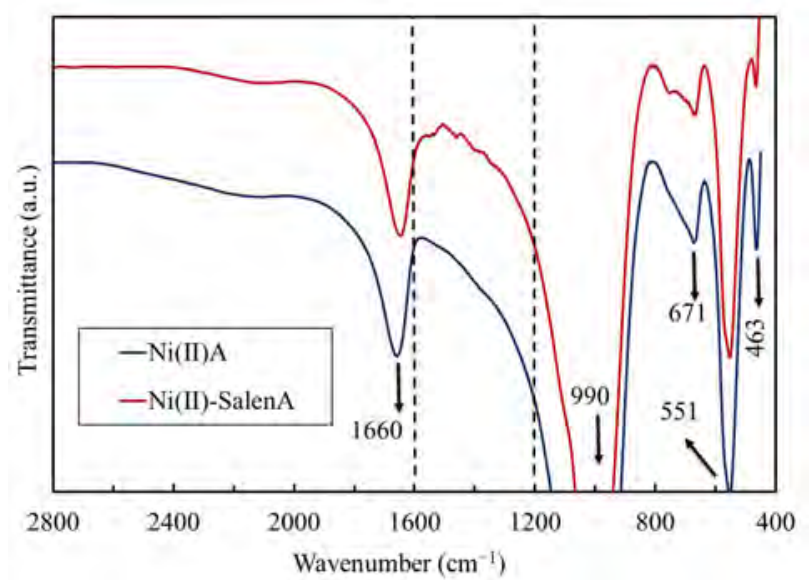

Fig. 2. Representative FT-IR spectra of nanozeolite Ni(II)A and Ni(II)-SalenA samples.
Fig. 3 illustrates an FESEM image, EDS spectrum, and elemental mapping for the prepared Ni(II)-SalenA composite. The EDS spectrum confirms the presence of $\mathrm{C}, \mathrm{O}, \mathrm{Na}, \mathrm{Al}, \mathrm{Si}$, and $\mathrm{Ni}$ in $\mathrm{Ni}(\mathrm{II})$-SalenA, with $\mathrm{Ni}$ belonging to SalenA. In addition, the elemental mapping analysis revealed homogeneous distributions of all these elements in the composite material, confirming the uniform distribution of $\mathrm{Ni}(\mathrm{II})$-Salen in the porous NaA nanozeolite framework.

Fig. 4(a) illustrates the nitrogen adsorption-desorption isotherms of NaA, Ni(II)A, and Ni(II)-SalenA at the temperature of liquid nitrogen. The isotherm of $\mathrm{NaA}$ nanozeolite was of type II according to Brunauer classification [38]. In addition, the hysteresis loops (type IV isotherm according to IUPAC classification) confirmed the existence of large porosities in nanozeolite NaA, Ni(II)A, and Ni(II)-SalenA [39]. The uptake of nitrogen increased steeply above a relative pressure of about 0.8. Type IV isotherms are observed for many industrial adsorbents [36,39]. Fig. 4(b) shows pore size distribution curves for NaA, $\mathrm{Ni}(\mathrm{II}) \mathrm{A}$, and Ni(II)-SalenA, which were evaluated from the adsorption branches of the isotherms. This figure shows that the pore diameters do not change with the addition of Ni(II) and $\mathrm{Ni}(\mathrm{II})-$ Salen, as all the curves are centered at about $3 \mathrm{~nm}$ $[40,41]$. Table 1 lists the surface areas and pore volumes of $\mathrm{NaA}, \mathrm{Ni}(\mathrm{II}) \mathrm{A}$, and Ni(II)-SalenA calculated by the $t$-plot method. As expected, encapsulation of the $\mathrm{Ni}(\mathrm{II})$-Salen complex in nanozeolite $\mathrm{NaA}$ leads to an apparent reduction in the surface area and pore volume of the nanozeolite host. The surface area of $\mathrm{NaA}\left(362.4 \mathrm{~m}^{2} / \mathrm{g}\right)$ was significantly reduced to 261.2 and $150.3 \mathrm{~m}^{2} / \mathrm{g}$ for Ni(II)A and Ni(II)-SalenA, respectively. A similar trend was also observed for the total pore volume, which decreased from $0.26 \mathrm{~cm}^{3} / \mathrm{g}$ for $\mathrm{NaA}$ to 0.18 and $0.14 \mathrm{~cm}^{3} / \mathrm{g}$ for $\mathrm{Ni}(\mathrm{II}) \mathrm{A}$ and $\mathrm{Ni}(\mathrm{II})-\mathrm{SalenA}$, respectively. This drastic reduction in the pore volume might originate from the presence of $\mathrm{Ni}(\mathrm{II})-$ Salen in the pores of $\mathrm{NaA}[38,42]$. It can be deduced that
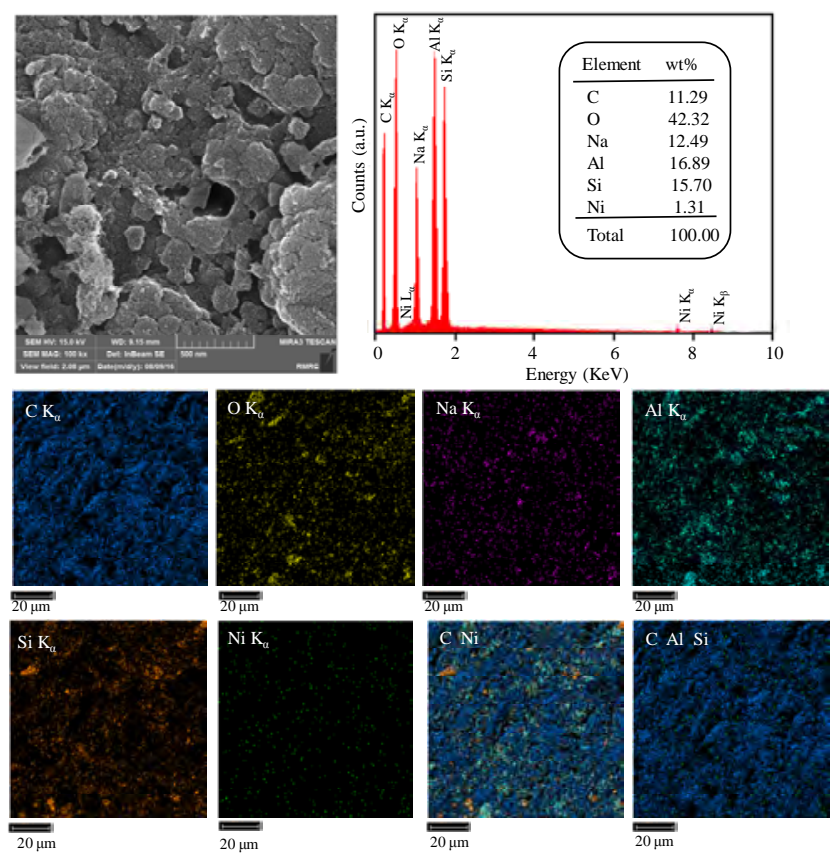

Fig. 3. FESEM-EDS analysis and elemental mapping of Ni(II)-SalenA. 

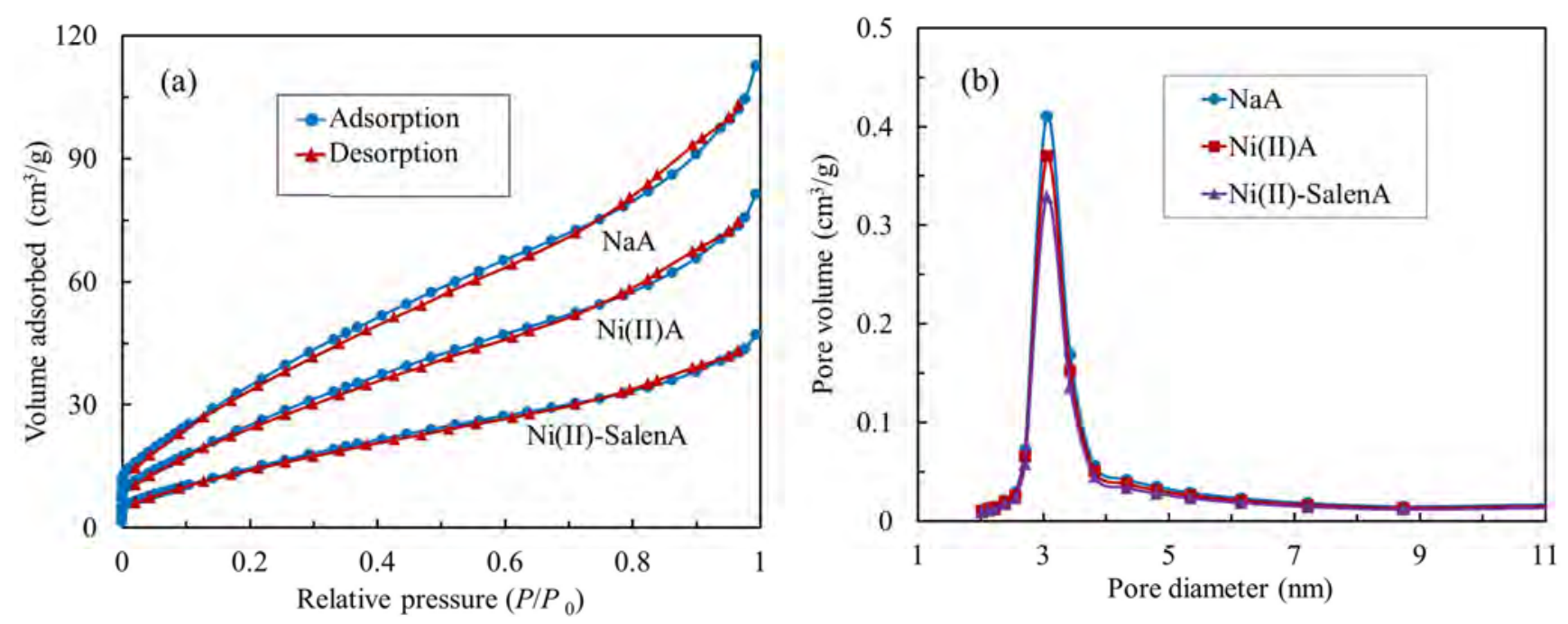

Fig. 4. (a) Nitrogen adsorption-desorption isotherms of nanozeolite NaA, Ni(II)A, and Ni(II)-SalenA at the temperature of liquid nitrogen. (b) Pore size distributions obtained from the adsorption branch of the corresponding isotherm according to the BJH method.

the $\mathrm{Ni}(\mathrm{II})-$ Salen complex is present in the cavities of $\mathrm{NaA}$ rather than on the external surface [25]. As can be seen in Table 1, the micropore volume is bigger than the mesopore volume and the micropore surface area is greater than the external surface area for all samples. Therefore, the porosities of synthesized nanozeolite $\mathrm{NaA}, \mathrm{Ni}(\mathrm{II}) \mathrm{A}$, and $\mathrm{Ni}(\mathrm{II})$-SalenA mostly consist of micropores.

\subsection{Electrochemical investigation of fabricated electrodes}

CV was used to investigate the electrochemical properties of the bare CPE and Ni(II)-SalenA/CPE in $5 \mathrm{mmol} / \mathrm{L} \mathrm{K}_{4} \mathrm{Fe}(\mathrm{CN})_{6}$ and $5 \mathrm{mmol} / \mathrm{L} \mathrm{K}_{3} \mathrm{Fe}(\mathrm{CN})_{6}$ solution containing $0.1 \mathrm{~mol} / \mathrm{L} \mathrm{KCl}$ (Fig. S1). The experimental results showed reproducible anodic and cathodic peaks ascribed to the $\mathrm{Fe}(\mathrm{CN})_{6}{ }^{3-} / \mathrm{Fe}(\mathrm{CN}) 6^{4-}$ redox couple at a scan rate of $20 \mathrm{mV} / \mathrm{s}$ on the surface of CPE and $\mathrm{Ni}(\mathrm{II})-$ SalenA/CPE. As can be seen in Fig. S1, the anodic and cathodic peak currents for Ni(II)-SalenA/CPE are higher than those for bare CPE. Peak-to-peak separations $\left(\Delta E_{\mathrm{p}}\right)$ of 210 and $100 \mathrm{mV}$ were observed for the $\mathrm{Fe}(\mathrm{CN})_{6}{ }^{3-} / \mathrm{Fe}(\mathrm{CN})_{6}{ }^{4-}$ redox couple on the surface of CPE and Ni(II)-SalenA/CPE, respectively, indicating that these systems are quasi-reversible [43]. The value of $\Delta E_{\mathrm{p}}$ for $\mathrm{Ni}(\mathrm{II})$-SalenA/CPE was much closer to the expected value $(59 \mathrm{mV})$ for a reversible one-electron process. This finding indicated that the electron-transfer kinetics of $\left[\mathrm{Fe}(\mathrm{CN})_{6}\right]^{4-} /\left[\mathrm{Fe}(\mathrm{CN})_{6}\right]^{3-}$ were facilitated at the

Table 1

Physical properties of nanozeolite NaA, Ni(II)A, and Ni(II)-SalenA determined from nitrogen adsorption-desorption isotherms.

\begin{tabular}{lcccccc}
\hline Sample & $\begin{array}{c}S_{\text {BET }^{\mathrm{a}}} \\
\left(\mathrm{m}^{2} / \mathrm{g}\right)\end{array}$ & $\begin{array}{c}S_{\text {Ext }^{\mathrm{b}}} \\
\left(\mathrm{m}^{2} / \mathrm{g}\right)\end{array}$ & $\begin{array}{c}S_{\text {mic }^{\mathrm{c}}} \\
\left(\mathrm{m}^{2} / \mathrm{g}\right)\end{array}$ & $\begin{array}{c}V_{\text {tot }^{\mathrm{d}}} \\
\left(\mathrm{cm}^{3} / \mathrm{g}\right)\end{array}$ & $\begin{array}{c}V_{\text {mic }^{\mathrm{e}}} \\
\left(\mathrm{cm}^{3} / \mathrm{g}\right)\end{array}$ & $\begin{array}{c}V_{\text {meso }^{\mathrm{f}}} \\
\left(\mathrm{cm}^{3} / \mathrm{g}\right)\end{array}$ \\
\hline $\mathrm{NaA}$ & 362.4 & 21.3 & 341.1 & 0.26 & 0.23 & 0.03 \\
$\mathrm{Ni}(\mathrm{II}) \mathrm{A}$ & 261.2 & 14.1 & 247.1 & 0.18 & 0.16 & 0.02 \\
$\mathrm{Ni}(\mathrm{II})-S a l e n \mathrm{~A}$ & 150.3 & 11.7 & 138.6 & 0.14 & 0.12 & 0.02 \\
\hline
\end{tabular}

${ }^{a}$ BET surface area. ${ }^{b}$ The external surface area. ${ }^{c}$ The micropore surface area. ${ }^{\text {d }}$ The total pore volume. e The micropore volume; both $S_{\text {Ext }}$ and $V_{\text {mic }}$ were obtained by the $t$-plot method. ${ }^{\mathrm{f}}$ The mesopore volume $\left(V_{\text {tot }}-V_{\text {mic }}\right)$.
$\mathrm{Ni}(\mathrm{II})-$ SalenA/CPE surface in contrast to that of the bare CPE.

FESEM was performed in order to analyze the surface structure of the fabricated CPE and Ni(II)-SalenA/CPE, as illustrated in Fig. 5. As can be seen in Fig. 5(a), the bare CPE consisted of a layer of irregular flakes of graphite powder isolated from each other. After the addition of Ni(II)-SalenA to the graphite powder to fabricate Ni(II)-SalenA/CPE, it can be seen that Ni(II)-SalenA was completely distributed on the surface of the electrode, indicating that Ni(II)-SalenA was irregularly incorporated into the CPE (Fig. 5(b)) [20,44]. In addition, Fig. 5(c) and (d) displays the EDS spectra of CPE and Ni(II)-SalenA/CPE, respectively. The data obtained from these spectra revealed that only carbon existed on the surface of CPE, whereas $\mathrm{C}, \mathrm{O}$,
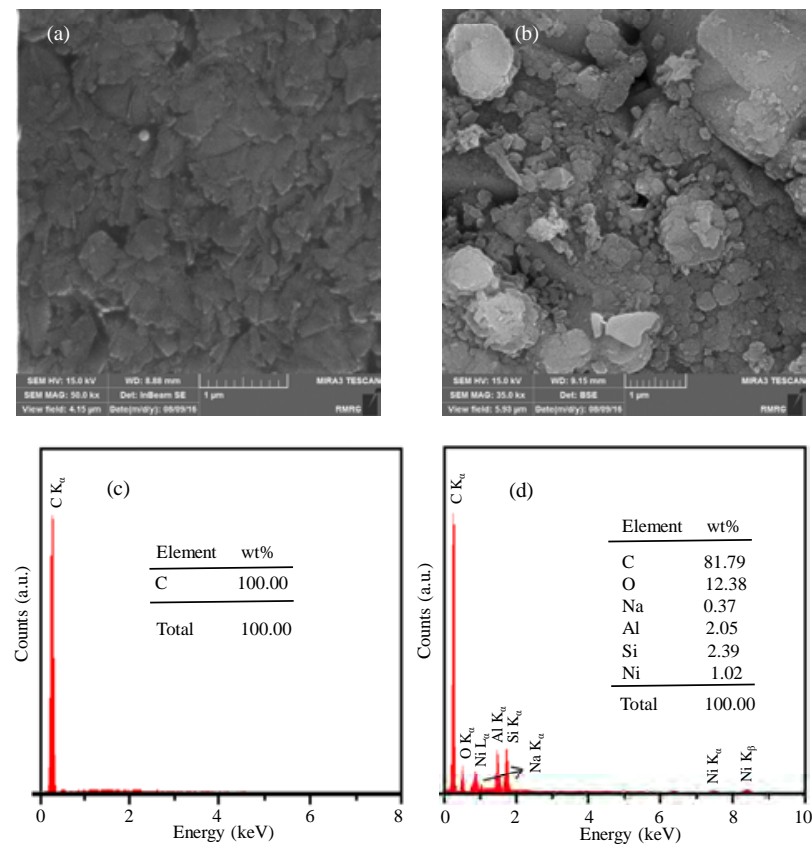

Fig. 5. Representative FESEM images of bare CPE (a) and Ni(II)-SalenA/CPE (b). EDS spectra of (c) bare CPE and (d) Ni(II)-SalenA/CPE. 
$\mathrm{Na}, \mathrm{Al}, \mathrm{Si}$, and $\mathrm{Ni}$ were present on the structure of Ni(II)-SalenA/CPE.

\subsection{Electrochemical behavior of Ni(II)-SalenA/CPE in alkaline media}

Fig. S2 illustrates consecutive cyclic voltammograms of $\mathrm{Ni}(\mathrm{II})-\mathrm{SalenA} / \mathrm{CPE}$ in $0.1 \mathrm{~mol} / \mathrm{L} \mathrm{NaOH}$ solution at a scan rate of $50 \mathrm{mV} / \mathrm{s}$. It is worth observing that a pair of redox peaks appears at 495 and $310 \mathrm{mV}$ in the first cycle, which is assigned to the $\mathrm{Ni}^{2+}($ Salen $) / \mathrm{Ni}^{3+}$ (Salen) redox couple. In the subsequent cycles, the anodic and cathodic peaks are shifted to negative potential values and eventually stabilized at 440 and $305 \mathrm{mV}$, providing evidence for the alteration of the active composition of Ni complexes as a result of repeated polarization [45]. The current growth with the number of potential cycles can be ascribed to progressive enrichment of the electroactive species $\mathrm{Ni}^{2+}$ (Salen) $(\mathrm{OH})_{2}$ converted from $\mathrm{Ni}^{2+}$ (Salen) on or near the surface of the modified electrode $[43,46,47]$. The inset in Fig. S2 depicts the anodic, cathodic, and formal potentials vs. the number of potential cycles. As can be seen, the peak potentials and the formal potential $E^{0^{\prime}}\left(0.5\left(E_{\mathrm{pa}}+E_{\mathrm{pc}}\right)\right)$ both reach stable values after about 50 cycles. Fig. S3 shows cyclic voltammograms of CPE and Ni(II)-SalenA/CPE in $0.1 \mathrm{~mol} / \mathrm{L} \mathrm{NaOH}$ at a scan rate of $20 \mathrm{mV} / \mathrm{s}$ in the absence of $\mathrm{N}_{2} \mathrm{H}_{4}$. The onset potentials for oxygen evolution were observed at 0.61 and $0.66 \mathrm{~V}$ on the surface of $\mathrm{Ni}(\mathrm{II})-\mathrm{SalenA} / \mathrm{CPE}$ and bare CPE, respectively, and the current for water oxidation was increased on the surface of Ni(II)-SalenA/CPE. This behavior is due to the catalytic effect of $\mathrm{Ni}(\mathrm{II})$ on the surface of $\mathrm{Ni}(\mathrm{II})$-SalenA/CPE and is in agreement with previous work for the $\mathrm{Ni}^{2+} / \mathrm{Ni}^{3+}$ redox couple $[13,25,27,43,48]$.

Typical cyclic voltammograms for the electrochemical behavior of Ni(II)-SalenA/CPE in $0.1 \mathrm{~mol} / \mathrm{L} \mathrm{NaOH}$ solution at various scan rates (0.01-1.0 V/s) are illustrated in Fig. S4. A pair of well-shaped redox peaks with a peak-to-peak potential separation $\left(\Delta E_{\mathrm{p}}\right)$ of $60 \mathrm{mV}$ was detected at a scan rate of $0.01 \mathrm{~V} / \mathrm{s}$. In addition, $\Delta E_{\mathrm{p}}$ increased with increasing scan rate, which indicated the presence of a limitation in the charge-transfer kinetics arising from chemical interactions between the electrolyte ions and the modified film $[48,49]$. According to a theory proposed by Laviron [50], at $\Delta E_{\mathrm{p}}>200 / n \mathrm{mV}$, the electron-transfer coefficient $(\alpha)$ can be calculated by measuring the variation of the peak potential $\left(E_{\mathrm{p}}\right)$ with respect to $\log v$ and the apparent charge-transfer rate constant $\left(k_{\mathrm{s}}\right)$ for electron transfer between the electrode and the surface layer can be calculated by measuring the $E_{\mathrm{p}}$ values, as given in the following equations [50,51]:

$$
\begin{gathered}
E_{\mathrm{pa}}=E^{0}+\left[\frac{R T}{(1-\alpha) n F}\right] \\
E_{\mathrm{pc}}=E^{0}+\left[\frac{R T}{\alpha n F}\right] \ln \left[\frac{\alpha n F v}{R T k_{\mathrm{s}}}\right]
\end{gathered}
$$

$\log k_{\mathrm{s}}=\alpha \log (1-\alpha)+(1-\alpha) \log \alpha-\log \left(\frac{R T}{n F v}\right)-\left(\frac{\alpha(1-\alpha) n F \Delta E_{\mathrm{p}}}{2.303 R T}\right)$

Inset (a) in Fig. S4 displays plots of $E_{\text {p }}$ with respect to $\log v$ in the range of $0.010-1.0 \mathrm{~V} / \mathrm{s}$ for both the anodic and cathodic peaks on $\mathrm{Ni}(\mathrm{II})-\mathrm{SalenA} / \mathrm{CPE}$ in $0.1 \mathrm{~mol} / \mathrm{L} \mathrm{NaOH}$. It can be seen that $E_{\mathrm{p}}$ is proportional to $\log v$ at $v>0.075 \mathrm{~V} / \mathrm{s}$, as confirmed by Laviron [50]. The value of $\alpha$ was found to be 0.584 , which indicated that the rate-limiting steps for the cathodic and anodic reactions might not be the same. In addition, the mean value of the charge-transfer rate constant $\left(k_{\mathrm{s}}\right)$ was calculated to be $0.087 \mathrm{~s}^{-1}$.

Inset (b) in Fig. S4 displays plots of the anodic and cathodic peak currents vs. $v$ at low values from 0.010 to $0.075 \mathrm{~V} / \mathrm{s}$. According to the slope of these two lines, the surface coverage of redox species $\left(\Gamma^{*}\right)$ on $\mathrm{Ni}(\mathrm{II})$-SalenA/CPE can be estimated using the following equation [52]:

$$
I_{\mathrm{p}}=\frac{n^{2} F^{2} A \Gamma^{*} v}{4 R T}
$$

where $I_{\mathrm{p}}, n$, and $A$ are the peak current, the number of electrons involved in the reaction $(n=1)$, and the surface area of the electrode $\left(0.12566 \mathrm{~cm}^{2}\right)$, respectively. $\Gamma^{*}$ was calculated to be about $2.75 \times 10^{-8} \mathrm{~mol} / \mathrm{cm}^{2}$, considering the mean of the anodic and cathodic currents. In addition, the mass of nickel loaded on the surface of Ni(II)-SalenA/CPE was obtained as $0.203 \mu \mathrm{g}$. For the higher potential scan rates of $0.1-1.0 \mathrm{~V} / \mathrm{s}$, the peak current density values are proportional to the square root of the scan rate, indicating a diffusion-controlled process, which reflects that the charge transfer of the $\mathrm{Ni}(\mathrm{OOH})($ Salen $) / \mathrm{Ni}(\mathrm{OH})_{2}$ (Salen) couple is limited by the relatively slow diffusion of $\mathrm{OH}^{-}$ions toward the film (inset (c) in Fig. S4) [26,53].

\subsection{Electrocatalytic activity of Ni(II)-SalenA/CPE for electrooxidation of hydrazine}

Fig. 6 illustrates cyclic voltammograms of bare CPE, Salen/CPE, NaA/CPE, Ni(II)A/CPE, and Ni(II)-SalenA/CPE in the absence and presence of $20 \mathrm{mmol} / \mathrm{L} \mathrm{N}_{2} \mathrm{H}_{4}$ in $0.1 \mathrm{~mol} / \mathrm{L}$ $\mathrm{NaOH}$ as a supporting electrolyte at a scan rate of $20 \mathrm{mV} / \mathrm{s}$. It can be seen that there are no electrochemical responses on the bare CPE, Salen/CPE, and NaA/CPE in the absence or presence of $\mathrm{N}_{2} \mathrm{H}_{4}$ (Fig. 6(a)-(c)). A pair of well-defined redox peaks with a large anodic peak current intensity $\left(j_{\mathrm{pa}}=0.8 \mathrm{~mA} / \mathrm{cm}^{2}\right)$ and a small peak-to-peak potential separation $\left(\Delta E_{\mathrm{p}}=100 \mathrm{mV}\right)$ is observed on $\mathrm{Ni}(\mathrm{II})$-SalenA/CPE in the absence of $\mathrm{N}_{2} \mathrm{H}_{4}$ (Fig. 6(e)). Meanwhile, a small anodic signal $\left(j \mathrm{pa}=0.4 \mathrm{~mA} / \mathrm{cm}^{2}\right)$ with $\Delta E_{\mathrm{p}}=$ $160 \mathrm{mV}$ is observed on the surface of Ni(II)A/CPE (Fig. 6(d)), suggesting that $\mathrm{Ni}(\mathrm{II})-$ SalenA in alkaline solution reacts with $\mathrm{OH}^{-}$to produce $\mathrm{Ni}(\mathrm{OH})_{2}$-SalenA, which acts as an active site for the redox process. In the absence of $\mathrm{N}_{2} \mathrm{H}_{4}$ in Fig. 6(e), the anodic peak located at $0.440 \mathrm{~V}$ corresponds to the oxidation of $\mathrm{Ni}(\mathrm{OH})_{2}$-SalenA/CPE to $\mathrm{Ni}(\mathrm{OOH})$-SalenA/CPE, and the cathodic peak positioned at $0.305 \mathrm{~V}$ is ascribed to the reverse transformation [46,47]. These results confirmed that the presence of $\mathrm{Ni}(\mathrm{II})-$ SalenA in the fabricated electrode had a great influence on improving the oxidation currents.

After addition of $\mathrm{N}_{2} \mathrm{H}_{4}$ to the supporting electrolyte, anodic electrocatalytic peaks were obtained for $\mathrm{Ni}(\mathrm{II}) \mathrm{A} / \mathrm{CPE}$ and $\mathrm{Ni}(\mathrm{II})-$ SalenA/CPE, and the catalytic current on the surface of $\mathrm{Ni}(\mathrm{II})-\mathrm{SalenA} / \mathrm{CPE}$ was about 3-fold greater than that obtained on $\mathrm{Ni}(\mathrm{II}) \mathrm{A} / \mathrm{CPE}$. Clearly, the larger catalytic current for $\mathrm{N}_{2} \mathrm{H}_{4}$ oxidation on $\mathrm{Ni}(\mathrm{II})$-SalenA/CPE relative to that on $\mathrm{Ni}(\mathrm{II}) \mathrm{A} / \mathrm{CPE}$ results from $\mathrm{Ni}(\mathrm{Salen})$, not $\mathrm{Ni}^{2+}$ ions. These results revealed 

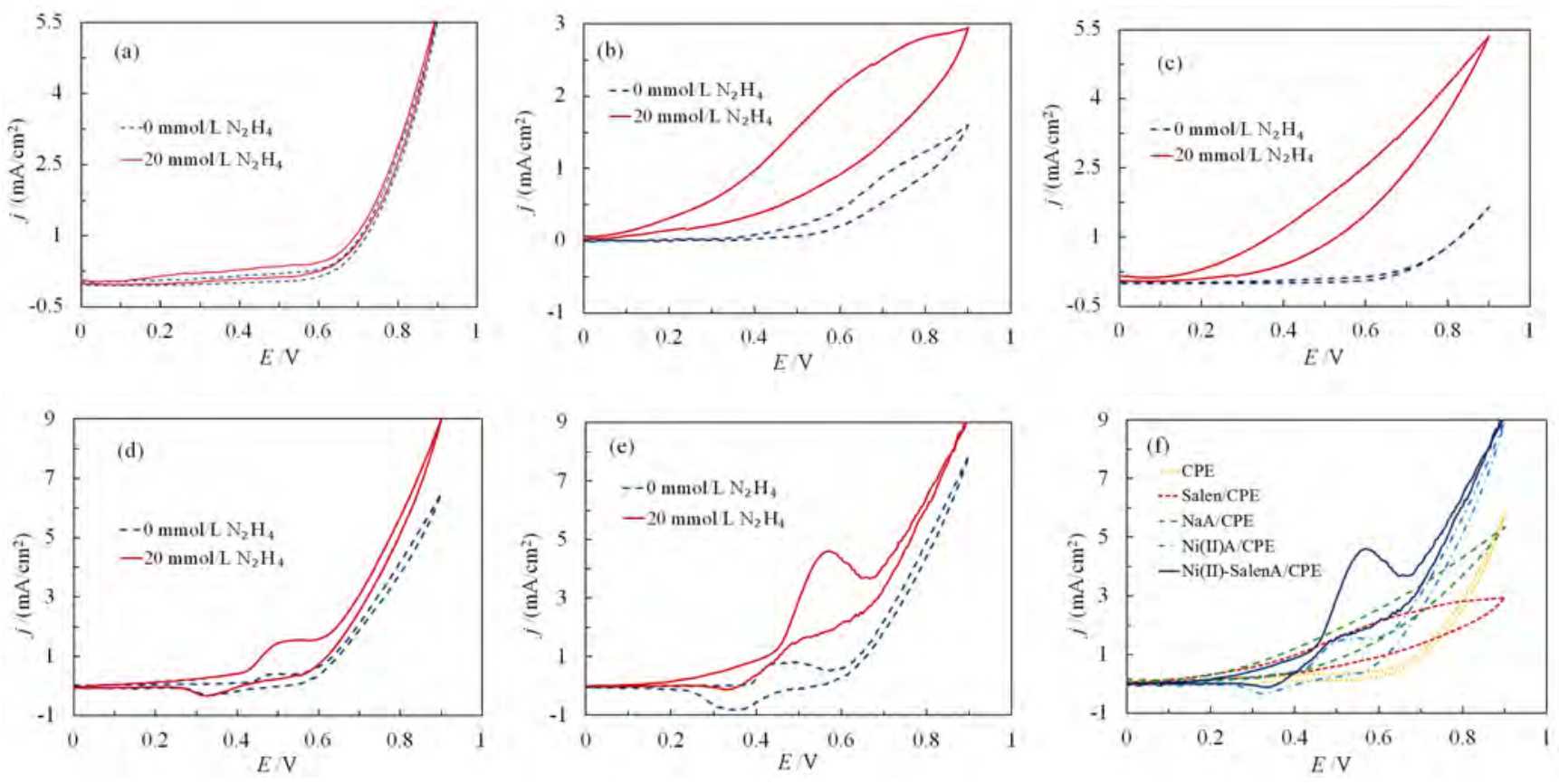

Fig. 6. Cyclic voltammograms of fabricated electrodes in the absence and presence of $20 \mathrm{mmol} / \mathrm{L} \mathrm{N}_{2} \mathrm{H}_{4}$ in $0.1 \mathrm{~mol} / \mathrm{L} \mathrm{NaOH}$ at a scan rate of $20 \mathrm{mV} / \mathrm{s}$. (a) bare CPE, (b) Salen/CPE, (c) NaA/CPE, (d) Ni(II)A/CPE, (e) Ni(II)-SalenA/CPE. (f) Cyclic voltammograms of all fabricated electrodes in the presence of $20 \mathrm{mmol} / \mathrm{L} \mathrm{N}_{2} \mathrm{H}_{4}$ in $0.1 \mathrm{~mol} / \mathrm{L} \mathrm{NaOH}$ at a scan rate of $20 \mathrm{mV} / \mathrm{s}$.

that the Ni(II)-Salen complex as an electron-transfer mediator plays an effective role in the $\mathrm{N}_{2} \mathrm{H}_{4}$ oxidation process [25-27]. For better comparison, the cyclic voltammograms of bare CPE, Salen/CPE, NaA/CPE, Ni(II)A/CPE, and Ni(II)-SalenA/CPE in the presence of $20 \mathrm{mmol} / \mathrm{L} \mathrm{N}_{2} \mathrm{H}_{4}$ are shown in Fig. 6(f). As can be seen in this figure, no signals for the oxidation of $\mathrm{N}_{2} \mathrm{H}_{4}$ appear on bare CPE, Salen/CPE, and NaA/CPE. In addition, the catalytic current on $\mathrm{Ni}(\mathrm{II})$-SalenA/CPE is greater than that on $\mathrm{Ni}(\mathrm{II}) \mathrm{A} / \mathrm{CPE}$. Upon complexation with the salen ligand, $\mathrm{Ni}(\mathrm{II})-$ SalenA/CPE exhibits a higher activity than Ni(II)A/CPE, which is attributed to an interaction between the central $\mathrm{Ni}^{2+}$ ions and the $\mathrm{H}_{2}$ Salen ligand. The partially filled $d$-orbitals of $\mathrm{Ni}^{2+}$ ions interact with the $\pi$-electron orbitals of the oxygen and nitrogen atoms in $\mathrm{H}_{2} \mathrm{Salen}$, which accelerates charge transfer between the metal ions and the ligand under an external electric field [27]. In addition, the encapsulated complex molecules in nanozeolite NaA may somewhat inhibit the solvent and electrolyte from approaching bulk redox sites. The ligand-centered process can make more molecules undergo electron transfer than $\mathrm{Ni}^{2+}$, and the adsorbed $\mathrm{Ni}(\mathrm{II})$-Salen complexes can act as mediators for improving the communication between intrazeolite complexes, thereby enhancing the electroactivity for $\mathrm{N}_{2} \mathrm{H}_{4}$ oxidation [25,27,54]. It can be noted that the synthesized nanozeolite $\mathrm{NaA}$ has nanocages of about $3 \mathrm{~nm}$ that are interconnected through channels of 0.8-1.2 nm. As a result, salen complexes can be encapsulated successfully in the supercages of the nanozeolite [40]. This arrangement enables interactions between partially coordinated $\mathrm{Ni}$ (Salen) molecules in adjacent sites in a nanocage through zeolite lattice oxygens, resulting in a redistribution of $d$ electrons in $\mathrm{Ni}^{2+}$ ions, which results in a great improvement in electrocatalytic performance.

As can be seen in Fig. 6(e), the oxidation peak appears at about $0.57 \mathrm{~V}$ for $\mathrm{N}_{2} \mathrm{H}_{4}$ oxidation on the $\mathrm{Ni}(\mathrm{II})$-SalenA/CPE surface and the cathodic peak current is also decreased. This result indicated that the applied modifier (Ni(II)-SalenA) in this process participates directly in the electrocatalytic oxidation of $\mathrm{N}_{2} \mathrm{H}_{4}$. Taking into account all these observations and in agreement with the literature [10-13,55], a mechanism for electrocatalytic oxidation of $\mathrm{N}_{2} \mathrm{H}_{4}$ at the $\mathrm{Ni}(\mathrm{II})$-SalenA/CPE surface can be suggested. This mechanism corresponds to that typically observed for mediated oxidation (electrocatalytic reaction, $\mathrm{EC}^{\prime}$ mechanism), as illustrated in the following equations. As shown in the chemical reaction $\left(\mathrm{C}^{\prime}\right), \mathrm{N}_{2} \mathrm{H}_{4}$ is oxidized by $\mathrm{NiOOH}-S a l e n A$, which is produced via an electrochemical reaction (E).

$\left[\left(\mathrm{Ni}(\mathrm{OH})_{2}{ }^{-}\right.\right.$SalenA/CPE $\left.)\right]+\mathrm{OH}^{-} \rightleftarrows[(\mathrm{NiOOH}-$ SalenA $/ \mathrm{CPE})]+\mathrm{H}_{2} \mathrm{O}+\mathrm{e}^{-}$

$4[(\mathrm{NiOOH}-$ SalenA/CPE $)]+\mathrm{N}_{2} \mathrm{H}_{4} \rightarrow 4\left[\left(\mathrm{Ni}(\mathrm{OH})_{2}\right.\right.$-SalenA/CPE $\left.)\right]+\mathrm{N}_{2}$

\subsection{Effect of hydrazine concentration and scan rate}

Fig. 7(a) illustrates the cyclic voltammograms of $\mathrm{Ni}(\mathrm{II})-S a l e n A / \mathrm{CPE}$ at various concentration of $\mathrm{N}_{2} \mathrm{H}_{4}(0-80$ $\mathrm{mmol} / \mathrm{L}$ ) in $0.1 \mathrm{~mol} / \mathrm{L} \mathrm{NaOH}$ solution at a scan rate of $20 \mathrm{mV} / \mathrm{s}$. In addition, Fig. 7(b) shows zoomed cyclic voltammograms for $0,3,20$, and $70 \mathrm{mmol} / \mathrm{L} \mathrm{N}_{2} \mathrm{H}_{4}$. As shown in Fig. 7(b), no reduction peak is observed at $\mathrm{N}_{2} \mathrm{H}_{4}$ concentrations greater than 20 mmol/L. An obvious gradual enhancement of the anodic peak current is observed with increasing $\mathrm{N}_{2} \mathrm{H}_{4}$ concentration, suggesting an interaction between $\mathrm{N}_{2} \mathrm{H}_{4}$ and the redox sites of the film confined at the surface of electrode. At concentrations above $60 \mathrm{mmol} / \mathrm{L}$, no remarkable increase in the anodic peak current is observed (Fig. 7(c)), indicating that upon increasing the concentration of $\mathrm{N}_{2} \mathrm{H}_{4}$, the onset potential of $\mathrm{Ni}(\mathrm{II})$ SalenA 

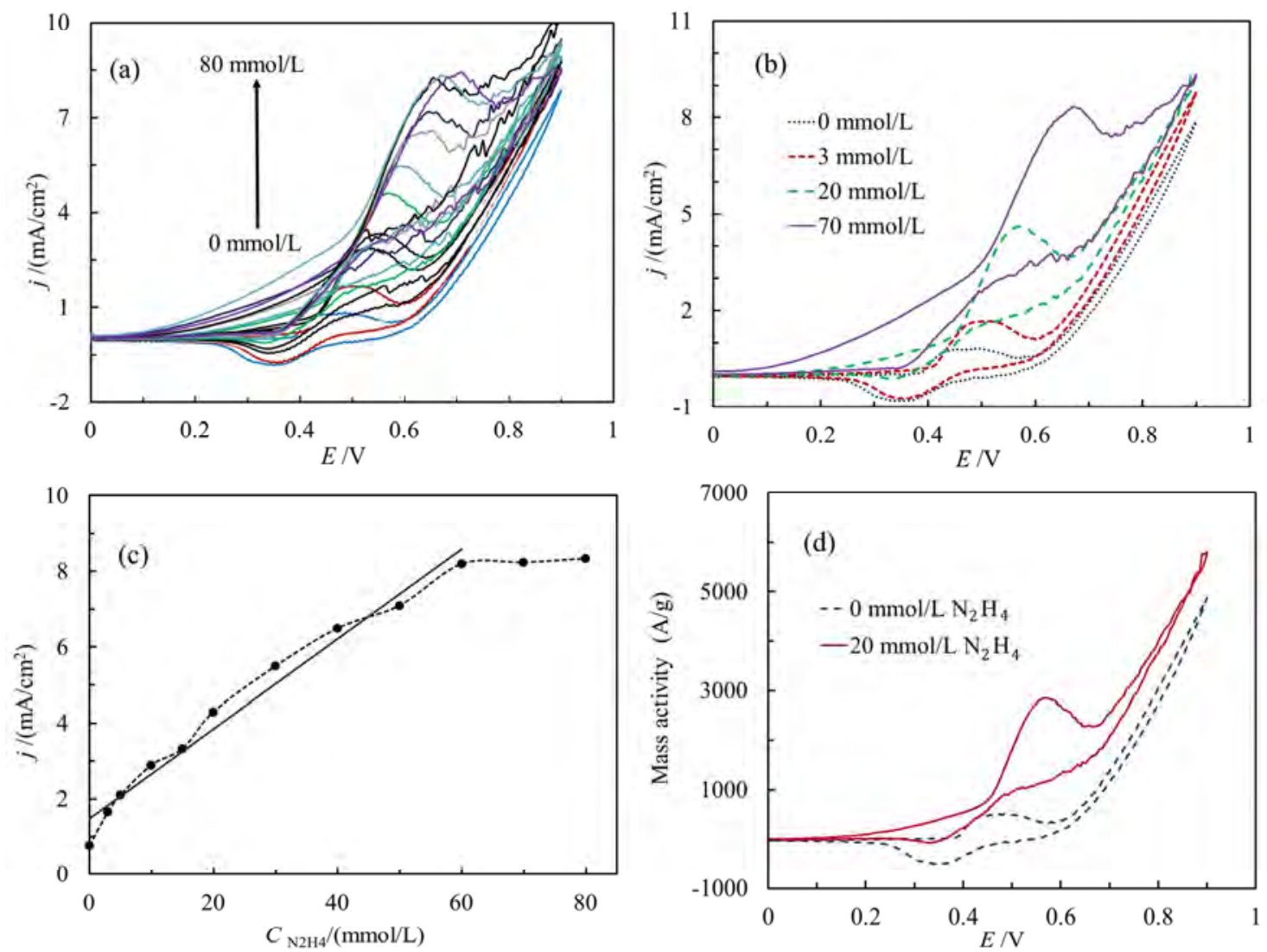

Fig. 7. (a) Cyclic voltammograms of $\mathrm{Ni}(\mathrm{II})-\mathrm{SalenA} / \mathrm{CPE}$ in $0.1 \mathrm{~mol} / \mathrm{L} \mathrm{NaOH}$ solution at a scan rate of $20 \mathrm{mV} / \mathrm{s}$ with different concentrations of $\mathrm{N}_{2} \mathrm{H}_{4}$ : 0.0 3.0, 5.0, 10.0, 15.0, 20.0, 30.0, 40.0, 50.0, 60.0, 70.0, and $80.0 \mathrm{mmol} / \mathrm{L}$. (b) Zoomed cyclic voltammograms for 0.0, 3.0, 20.0, and 70.0 mmol/L $\mathrm{N}_{2} \mathrm{H}_{4}$. (c) Plot of $j$ vs. $\mathrm{N}_{2} \mathrm{H}_{4}$ concentration. (d) Mass activity diagram of $\mathrm{Ni}(\mathrm{II})-\mathrm{SalenA} / \mathrm{CPE}$ in the absence and presence of $20.0 \mathrm{mmol} / \mathrm{L} \mathrm{N} \mathrm{H}_{4}$.

oxidation moves to positive values. This behavior is possibly due to the adsorption of intermediates on the remaining active sites, which hinders further oxidation of $\mathrm{N}_{2} \mathrm{H}_{4}$ as a greater overpotential is necessary for the oxidation of $\mathrm{N}_{2} \mathrm{H}_{4}$ [26,56]. Thus, $60 \mathrm{mmol} / \mathrm{L} \mathrm{N}_{2} \mathrm{H}_{4}$ represented the optimum concentration, above which the adsorption of oxidation products at the surface of the modified electrode may obstruct further oxidation. In addition, it can be noted that at high concentrations of $\mathrm{N}_{2} \mathrm{H}_{4}$, there appears to be an obvious deviation from the linear response, most probably owing to kinetic limitation [48]. The normalized current voltammogram for the $\mathrm{N}_{2} \mathrm{H}_{4}$ oxidation process at the Ni(II)-SalenA/CPE surface (i.e., current normalized by the mass of loaded $\mathrm{Ni}^{2+}$ ) is displayed in Fig. 7(d). The mass of loaded $\mathrm{Ni}^{2+}$ was determined from the surface coverage [48].

In order to further clarify the electrooxidation mechanism of $\mathrm{N}_{2} \mathrm{H}_{4}$ on $\mathrm{Ni}(\mathrm{II})$-SalenA/CPE, the effect of the potential scan rate on the cyclic voltammetric response was considered at a constant concentration of $\mathrm{N}_{2} \mathrm{H}_{4}$ (i.e., $10.0 \mathrm{mmol} / \mathrm{L}$ ) in $0.1 \mathrm{~mol} / \mathrm{L}$ $\mathrm{NaOH}$, as depicted in Fig. 8(a). It can be observed that with increasing potential scan rate, the anodic peak potential shifts to more positive values, whereas the cathodic peak potential shifts toward more negative values owing to a kinetic limitation in the reaction between the redox sites of $\mathrm{Ni}(\mathrm{II})$-SalenA/CPE and $\mathrm{N}_{2} \mathrm{H}_{4}$. In addition, it can be found that the cathodic peak current increases with the scan rate because there is not enough time at high scan rates for the catalytic reaction be- tween $\mathrm{N}_{2} \mathrm{H}_{4}$ and $\mathrm{Ni}(\mathrm{III})-$ SalenA, some of which is then reduced during the reverse scan. The increase in the peak current with the scan rate can be considered to indicate adsorption or diffusion control of the process.

A plot of $j_{\text {pa }}$ vs. $v^{1 / 2}$ in the range of $0.01-1.0 \mathrm{~V} / \mathrm{s}$ was found to be linear (Fig. 8(b)); meanwhile, a plot of $j_{\text {pa }}$ vs. $v$ did not show a linear curve (Fig. 8(c)). This observation suggested that this process is a diffusion-controlled process rather than a surface-controlled process $[20,48,57]$. A slope of 1.0 or 0.5 is expected for $\log j_{\mathrm{pa}}$ vs. $\log v$ plots when an adsorption or diffusion process is included, respectively $[27,48]$. A linear region is observed in the plot of $\log j_{\text {pa }}$ vs. $\log v$ for the oxidation of $\mathrm{N}_{2} \mathrm{H}_{4}$ on $\mathrm{Ni}(\mathrm{II})$-SalenA/CPE with a slope of 0.4118 (Fig. 8(d)), which is close to the theoretically expected value of 0.5 for a purely diffusion-controlled current. The small difference from the theoretical value probably arises from a kinetic limitation in the overall reaction [43]. A plot of the scan-rate-normalized current intensity $\left(j_{\mathrm{pa}} / v^{1 / 2}\right)$ vs. $v$ is depicted in Fig. 8(e). The observed polynomial decrease in the plot corresponds to an $\mathrm{EC}^{\prime}$ process, which emphasizes that a subsequent irreversible chemical step is included in the overall process $[51,57]$.

A Tafel plot ( $\log I_{\mathrm{p}}$ vs. $\left.E_{\mathrm{p}}\right)$ was constructed using the data derived from the rising part of the current-voltage curve recorded for $10 \mathrm{mmol} / \mathrm{L} \mathrm{N}_{2} \mathrm{H}_{4}$ on $\mathrm{Ni}(\mathrm{II})$-SalenA/CPE at a scan rate of 10 $\mathrm{mV} / \mathrm{s}$ (Fig. 8(f)). This rising part of the voltammogram, known as the Tafel region, is affected by the electron transfer kinetics 

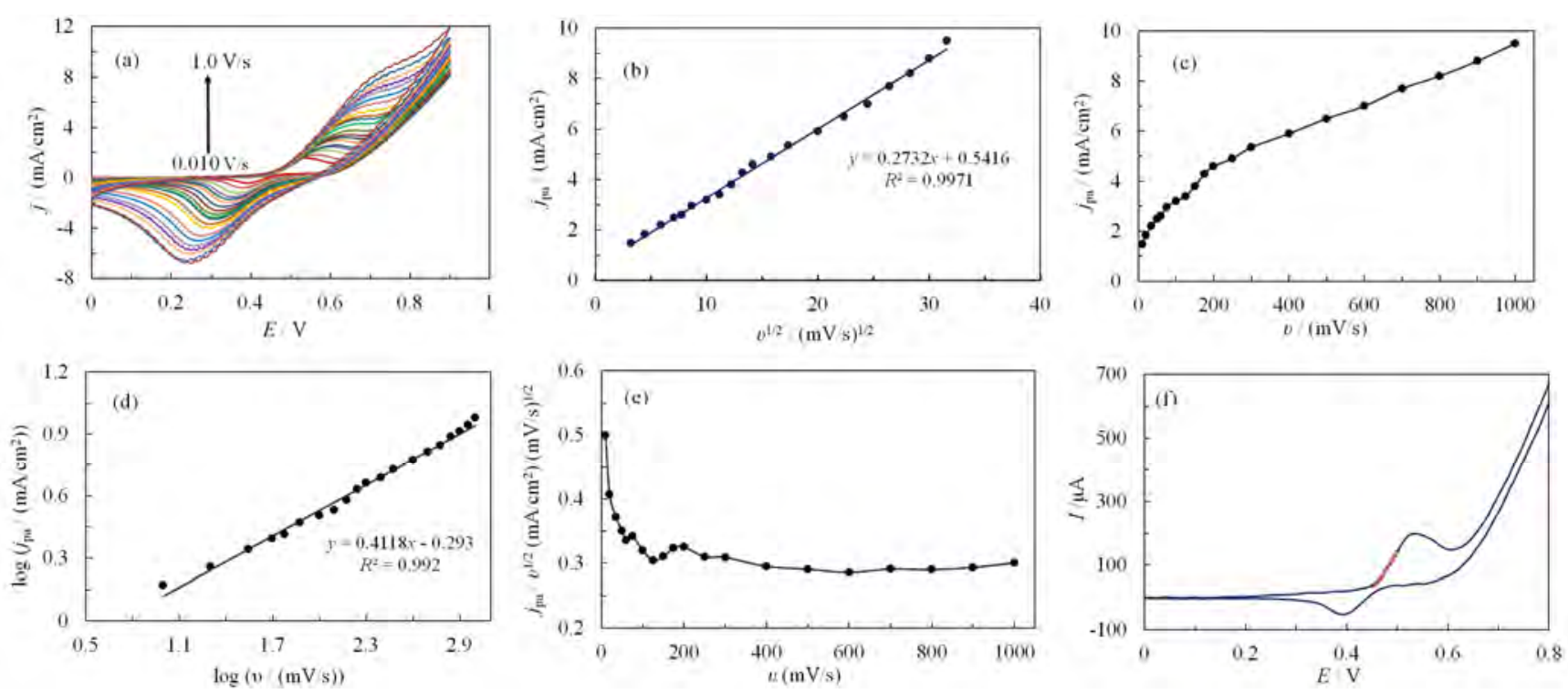

Fig. 8. (a) Cyclic voltammograms recorded on $\mathrm{Ni}(\mathrm{II})$-SalenA/CPE in the presence of $10 \mathrm{mmol} / \mathrm{L} \mathrm{N}_{2} \mathrm{H}_{4}$ in $0.1 \mathrm{~mol} / \mathrm{L} \mathrm{NaOH}$ at various scan rates; from inner to outer: $0.010,0.020,0.035,0.050,0.060,0.075,0.100,0.125,0.150,0.175,0.200,0.250,0.300,0.400,0.500,0.600,0.700,0.800,0.900$, and 1.0 V/s. Plots of $j_{\text {pa }}$ Vs. $v$ (b), $j_{\text {pa }}$ vs. $v^{1 / 2}$ (c), $\log j_{\text {pa }}$ vs. $\log v(\mathrm{~d})$, and $j_{\mathrm{pa}} / v^{1 / 2}$ vs. $v$ (e). (f) Cyclic voltammogram of Ni(II)-SalenA/CPE in the presence of 10 $\mathrm{mmol} / \mathrm{L} \mathrm{N}_{2} \mathrm{H}_{4}$ in $0.1 \mathrm{~mol} / \mathrm{L} \mathrm{NaOH}$ at a scan rate of $10 \mathrm{mV} / \mathrm{s}$. The inset in (f) shows the Tafel plot corresponding to this voltammogram.

between $\mathrm{N}_{2} \mathrm{H}_{4}$ and the modified electrode. The Tafel slope is equal to $n(1-\alpha) F / 2.303 R T$, where $n$ is the number of electrons in the rate-determining step, $\alpha$ is the electron transfer coefficient, and $F, R$, and $T$ have their usual meanings. As can be seen in the inset of Fig. 8(f), a slope of $6.07 \mathrm{~V} /$ decade was obtained, which indicated that the rate-limiting step was a one-electron-transfer process [2]. In addition, the charge-transfer coefficient, $\alpha$, was determined to be 0.64 .

From the plot of $I_{\mathrm{p}} \mathrm{vs} . v^{1 / 2}$, the number of electrons $(n)$ involved in the overall reaction can be obtained according to the following equation for a totally irreversible diffusion-controlled process [52]:

$$
I_{\mathrm{p}}=3.01 \times 10^{5} n\left[(1-\alpha) n_{\alpha}\right]^{1 / 2} A C D^{1 / 2} v^{1 / 2}
$$

The calculated slope of the $I_{\mathrm{p}}$ vs. $v^{1 / 2}$ plot is 3.43 $\mu \mathrm{A} /(\mathrm{mV} \cdot \mathrm{s})^{1 / 2}$, which corresponds to the total number of electrons transferred during the catalytic oxidation of $\mathrm{N}_{2} \mathrm{H}_{4}$ of 4.0 $(n=4.4)$, considering $(1-\alpha) n_{\alpha}=0.36, C=1.0 \times 10^{-5} \mathrm{~mol} / \mathrm{cm}^{3}$, and $D=1.18 \times 10^{-7} \mathrm{~cm}^{2} / \mathrm{s}$, as obtained by chronoamperometry (see below), and $A=0.12566 \mathrm{~cm}^{2}$. On the basis of this study and that reported in the literature [58], the following mechanism can be suggested for the oxidation of $\mathrm{N}_{2} \mathrm{H}_{4}$ on the surface of $\mathrm{Ni}(\mathrm{II})$-SalenA/CPE in alkaline solution, considering that $\mathrm{N}_{2} \mathrm{H}_{4}$ is in its unprotonated form in $0.1 \mathrm{~mol} / \mathrm{L} \mathrm{NaOH}$ solution:

$$
\begin{aligned}
& \mathrm{N}_{2} \mathrm{H}_{4}+\mathrm{OH}^{-} \rightarrow \mathrm{N}_{2} \mathrm{H}_{3}+\mathrm{H}_{2} \mathrm{O}+\mathrm{e}^{-} \\
& \mathrm{N}_{2} \mathrm{H}_{3}+3 \mathrm{OH}^{-} \rightarrow \mathrm{N}_{2}+3 \mathrm{H}_{2} \mathrm{O}+3 \mathrm{e}^{-} \\
& \text {(slow) }
\end{aligned}
$$

The rate-determining step involves the transfer of one electron followed by a three-electron process to give $\mathrm{N}_{2}$ and $\mathrm{H}_{2} \mathrm{O}$ as the final products. The overall reaction equation can be expressed by the following reaction, showing that $\mathrm{N}_{2} \mathrm{H}_{4}$ oxidation on Ni(II)-SalenA/CPE produces nitrogen and water [10].

$$
\mathrm{N}_{2} \mathrm{H}_{4}+4 \mathrm{OH}^{-} \rightarrow \mathrm{N}_{2}+4 \mathrm{H}_{2} \mathrm{O}+4 \mathrm{e}^{-}
$$

\subsection{Chronoamperometric studies}

Chronoamperometry was used to measure the catalytic rate constant and diffusion coefficient of $\mathrm{N}_{2} \mathrm{H}_{4}$ on the surface of the modified electrode. Fig. 9 exhibits double-step chronoamperograms for the redox process recorded by setting the potential of Ni(II)-SalenA/CPE at 0.65 and $0.30 \mathrm{~V}$ vs. $\mathrm{Ag}|\mathrm{AgCl}| \mathrm{KCl}$ ( $3 \mathrm{~mol} / \mathrm{L}$ ) in the absence and presence of different concentrations of $\mathrm{N}_{2} \mathrm{H}_{4}$. Plots of $I_{\text {cat }} / I_{\mathrm{L}}$ vs. the square root of time $\left(t^{1 / 2}\right)$ exhibited a linear dependency (inset (a) in Fig. 9). The catalytic rate constant $\left(k_{\text {cat }}\right)$ for the electrocatalytic oxidation of $\mathrm{N}_{2} \mathrm{H}_{4}$ on the active sites of the modified electrode can be estimated according to the following equation $[56,59]$ :

$$
\frac{I_{c a t}}{I_{L}}=\left(\pi k_{c a t} c_{0}\right)^{1 / 2} t^{1 / 2}
$$

where $I_{\text {cat }}$ and $I_{\mathrm{L}}$ are the currents in the presence and absence of $\mathrm{N}_{2} \mathrm{H}_{4}$, respectively, $k_{\text {cat }}$ is the catalytic rate constant $\left(\mathrm{cm}^{3} /(\mathrm{mol} \cdot \mathrm{s})\right), c_{0}$ is the bulk concentration of $\mathrm{N}_{2} \mathrm{H}_{4}\left(\mathrm{~mol} / \mathrm{cm}^{3}\right)$, and $t$ is the elapsed time (s). From the slopes of the $I_{\text {cat }} / I_{\mathrm{L}}$ vs. $t^{1 / 2}$ plots for all concentrations, the mean value of $k_{\text {cat }}$ was determined to be $1.03 \times 10^{5} \mathrm{~cm}^{3} /(\mathrm{mol} \cdot \mathrm{s})$. Table 2 compares the catalytic rate constant obtained in this work with those reported by others in the literature. As shown in Table 2, the catalytic rate constant for $\mathrm{N}_{2} \mathrm{H}_{4}$ oxidation on the surface of $\mathrm{Ni}(\mathrm{II})-$ SalenA/CPE is larger than those reported in the literature. This is probably because $\mathrm{N}_{2} \mathrm{H}_{4}$ as the electron transfer media has an inherently higher apparent electron transfer rate constant, showing good electrochemical properties. Therefore, $\mathrm{Ni}(\mathrm{II})-$ SalenA/CPE can overcome the kinetic limitation to some extent for $\mathrm{N}_{2} \mathrm{H}_{4}$ electrooxidation by a catalytic process and can decrease the overpotential for the oxidation of $\mathrm{N}_{2} \mathrm{H}_{4}$.

A plot of $I$ vs. $t^{-1 / 2}$ shows a linear dependence, which indicates diffusion-controlled behavior, and this result is in good agreement with the CV experiments. For an electroactive material, the current response under diffusion control is described by the Cottrell equation $[43,48,52]$ : 


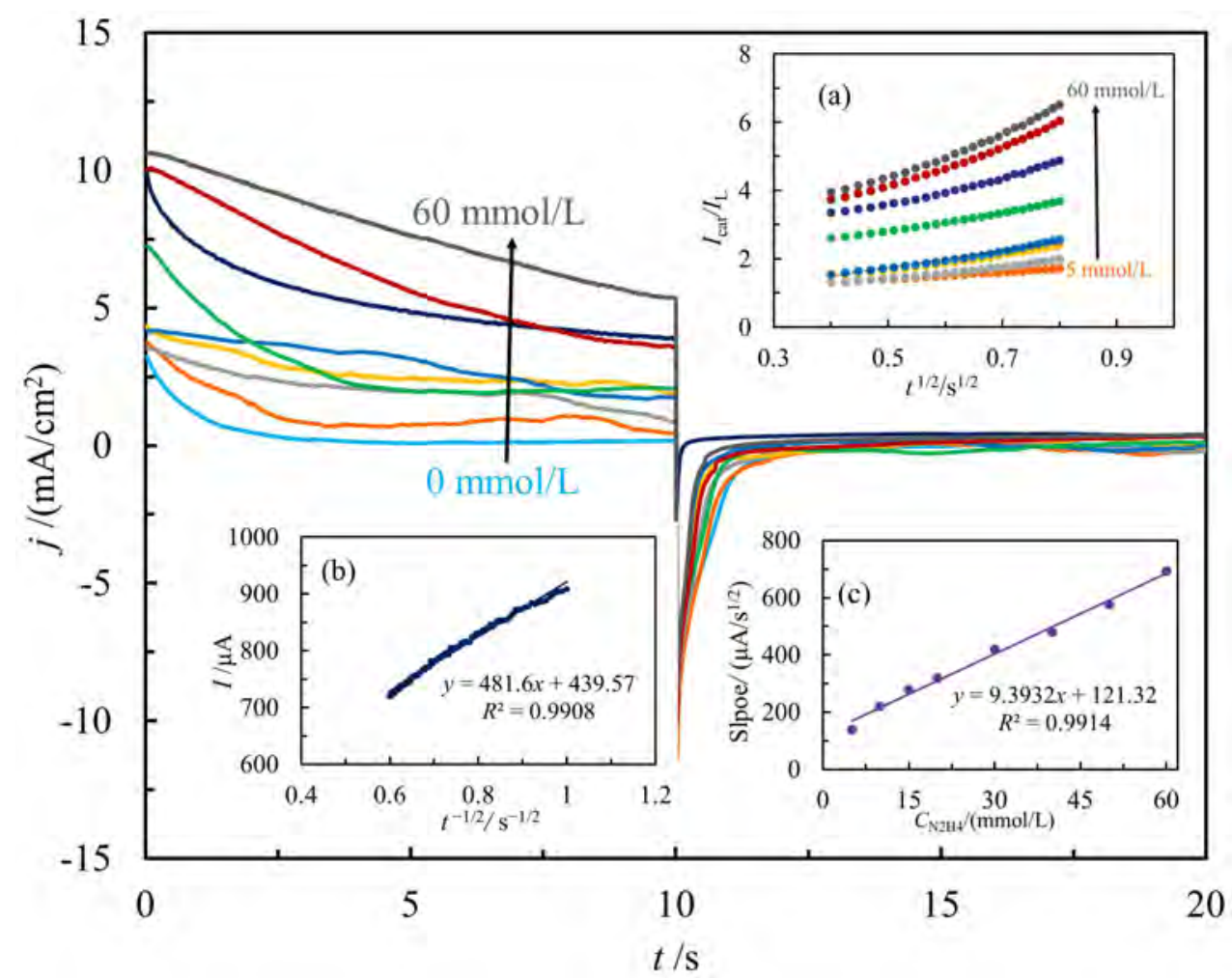

Fig. 9. Double-step chronoamperograms of Ni(II)-SalenA/CPE in $0.1 \mathrm{~mol} / \mathrm{L} \mathrm{NaOH}$ solution in the absence and presence of 5, 10, 15, 20, 30, 40, 50, and $60 \mathrm{mmol} / \mathrm{L} \mathrm{N}_{2} \mathrm{H}_{4}$. The potential steps were 0.65 and $0.30 \mathrm{~V} \mathrm{vs}$. Ag|AgCl|KCl ( $3 \mathrm{~mol} / \mathrm{L}$ ). Inset (a) shows the dependence of $I_{\text {cat }} / \mathrm{I}_{\mathrm{L}}$ on $t^{1 / 2}$ at each concentration of $\mathrm{N}_{2} \mathrm{H}_{4}$. Inset (b) shows the dependence of $I$ on $t^{-1 / 2}$ for $40 \mathrm{mmol} / \mathrm{L} \mathrm{N}_{2} \mathrm{H}_{4}$. Inset (c) shows a plot of the slopes of the straight lines vs. $\mathrm{N}_{2} \mathrm{H}_{4}$ concentration.

$$
I=n F A c D^{1 / 2} \pi^{-1 / 2} t^{-1 / 2}
$$

where $c$ is the bulk concentration of $\mathrm{N}_{2} \mathrm{H}_{4}\left(\mathrm{~mol} / \mathrm{cm}^{3}\right), D$ is the diffusion coefficient $\left(\mathrm{cm}^{2} / \mathrm{s}\right), A$ is the electrode area $(0.12566$ $\mathrm{cm}^{2}$ ), and $I$ is the current controlled by the diffusion of $\mathrm{N}_{2} \mathrm{H}_{4}$ from the bulk solution to the electrode/solution interface. Inset (b) in Fig. 9 displays the experimental plot of $I$ vs. $t^{-1 / 2}$ for 40 mmol/L $\mathrm{N}_{2} \mathrm{H}_{4}$ at the surface of Ni(II)-SalenA/CPE. The same curve was plotted for each concentration and then the slopes of the resulting straight lines were plotted vs. $\mathrm{N}_{2} \mathrm{H}_{4}$ concentration (inset (c) in Fig. 9) [56]. From the slope of the resulting plot and using the Cottrell equation, the mean value of $D$ was determined to be $1.18 \times 10^{-7} \mathrm{~cm}^{2} / \mathrm{s}$ in the range of $5-60 \mathrm{mmol} / \mathrm{L}$ $\mathrm{N}_{2} \mathrm{H}_{4}$. A comparison of the obtained $D$ value with other diffusion-coefficient values in the literature was performed, as presented in Table 2.

It should be noted that a comparison with other catalysts reported in the literature is rather difficult owing to various factors, such as concentration of electrolyte, potential sweep rate, and concentration of $\mathrm{N}_{2} \mathrm{H}_{4}$, which affect the activity of electrocatalysts toward $\mathrm{N}_{2} \mathrm{H}_{4}$ oxidation. However, we have endeavored to prepare a rough comparison of the electrocatalytic data with previous research on metal catalysts available in the literature. It seems that Ni(II)-SalenA/CPE can act as a comparable catalyst for hydrazine hydrate oxidation. As can be seen, the modified electrode shows good electrocatalytic activity toward $\mathrm{N}_{2} \mathrm{H}_{4}$ oxidation in terms of anodic peak potential compared with G/NiCuCo [10], $\mathrm{CuO} / \mathrm{NiO}$ composite nanofibers [13], Ni(II)-BA-MWCNT-PE [60], RGSs/GCE [61], and
Ni(II)(Salen)Y/GCE [62]. The $k_{\text {cat }}$ value on the $\mathrm{Ni}(\mathrm{II})-$ SalenA/CPE surface is comparable to $k_{\text {cat }}$ values on the surface of various electrodes reported in Table 2. In addition, the data in this table indicate that the Ni(II)-SalenA modified electrode can overcome the kinetic limitation to some extent for $\mathrm{N}_{2} \mathrm{H}_{4}$ electrooxidation by a catalytic process and can decrease the overpotential for the oxidation reaction of $\mathrm{N}_{2} \mathrm{H}_{4}$ [27].

\subsection{Chronocoulometric studies}

The electrocatalytic oxidation of $\mathrm{N}_{2} \mathrm{H}_{4}$ on $\mathrm{Ni}(\mathrm{II})-\mathrm{SalenA} / \mathrm{CPE}$ was investigated using the chronocoulometry technique. Fig. 10 shows the double-step chronocoulomograms in the absence and presence of different concentrations of $\mathrm{N}_{2} \mathrm{H}_{4} \quad$ (5-60 $\mathrm{mmol} / \mathrm{L}$ ) with applied potential steps of 0.65 and $0.30 \mathrm{~V}$ vs. $\mathrm{Ag}|\mathrm{AgCl}| \mathrm{KCl}$ (3 mol/L). The chronocoulometric curve of $\mathrm{Ni}(\mathrm{II})-$ SalenA/CPE in the blank solution $(0.1 \mathrm{~mol} / \mathrm{L} \mathrm{NaOH})$ displayed an almost symmetrical shape, which indicates that almost equivalent charges are consumed for the oxidation and reduction of surface-confined $\mathrm{Ni}(\mathrm{OH})_{2} / \mathrm{NiOOH}$ sites. A level line appeared when the potential was stepped down to $0.30 \mathrm{~V}$, implying that the electrooxidation processes are irreversible $[27,52]$. This result showed similar behavior to that described above using $\mathrm{CV}$ and chronoamperometry techniques. The charge value associated with forward chronocoulometry was greater than that observed for backward chronocoulometry in the presence of $\mathrm{N}_{2} \mathrm{H}_{4}$.

The chronocoulometry technique was also used to estimate 
Table 2

Comparison of the electrocatalytic activity of $\mathrm{Ni}(\mathrm{II})$-SalenA/CPE for $\mathrm{N}_{2} \mathrm{H}_{4}$ oxidation with those of some previously reported catalysts.

\begin{tabular}{|c|c|c|c|c|c|}
\hline Description & $\begin{array}{c}\text { Electron transfer rate } \\
\text { constant, } k_{\mathrm{s}}\left(\mathrm{s}^{-1}\right)\end{array}$ & $\begin{array}{l}\text { Heterogeneous rate con- } \\
\text { stant, } k_{\text {cat }}\left(\mathrm{cm}^{3} /(\mathrm{mol} \cdot \mathrm{s})\right)\end{array}$ & $\begin{array}{l}\text { Diffusion coeffi- } \\
\text { cient, } D\left(\mathrm{~cm}^{2} / \mathrm{s}\right)\end{array}$ & $\begin{array}{l}\text { Peak potential } \\
\left(E_{\mathrm{p}}\right) \text { vs. RHE }{ }^{\mathrm{m}}\end{array}$ & Ref. \\
\hline$\overline{\mathrm{Au}-\mathrm{SH}-\mathrm{SiO}_{2} @ \mathrm{Cu}-\mathrm{MOF} / \mathrm{GCE}^{\mathrm{a}}}$ & - & $1.67 \times 10^{3}$ & $4.15 \times 10^{-6}$ & 1.14 & {$[2]$} \\
\hline CuNPs-PANI-Nano-ZSM-5 b & - & $9.8 \times 10^{4}$ & $8.4 \times 10^{-6}$ & 1.30 & [7] \\
\hline $\mathrm{G} / \mathrm{NiCuCo}{ }^{\mathrm{c}}$ & - & - & $6.28 \times 10^{-6}$ & 1.66 & {$[10]$} \\
\hline NPA-NiCuP electrode ${ }^{d}$ & - & $4.29 \times 10^{4}$ & - & 1.37 & {$[11]$} \\
\hline $\mathrm{CuO} / \mathrm{NiO}$ composite nanofibers & - & - & - & 1.61 & {$[13]$} \\
\hline Modified MWCNT paste electrode & - & $4.93 \times 10^{3}$ & $9.5 \times 10^{-4}$ & 0.81 & {$[14]$} \\
\hline $\mathrm{MBCPE} / \mathrm{Fe}_{3} \mathrm{O}_{4} \mathrm{NPs} / \mathrm{DPB}$ e & - & $5.1 \times 10^{3}$ & $7.19 \times 10^{-6}$ & 0.76 & [17] \\
\hline $\mathrm{Au} /$ titanium dioxide nanotubes & - & - & $4.1 \times 10^{-5}$ & - & [58] \\
\hline DBC-IL/CNPE ${ }^{f}$ & 11 & $3.95 \times 10^{4}$ & $1.1 \times 10^{-5}$ & 0.78 & {$[63]$} \\
\hline Ni(II)-BA-MWCNT-PE g & 2.21 & $4.78 \times 10^{4}$ & $3.58 \times 10^{-5}$ & 1.54 & {$[60]$} \\
\hline RGSs/GCE ${ }^{1}$ & - & - & - & 1.86 & {$[61]$} \\
\hline Ni(II)(Salen)Y/GCE & 7.74 & $1.54 \times 10^{8}$ & $3.47 \times 10^{-7}$ & 1.57 & {$[62]$} \\
\hline Co(II)BBAEDI-MWCNT-MCPE h & 1.5 & - & $4.5 \times 10^{-6}$ & 0.85 & {$[64]$} \\
\hline Quinizarine/GCE & 4.44 & $4.83 \times 10^{3}$ & $1.1 \times 10^{-6}$ & - & [65] \\
\hline GC/Nafion/poly(Ni) & - & $1.6 \times 10^{3}$ & $1.3 \times 10^{-8}$ & - & {$[66]$} \\
\hline $\mathrm{NiPCNF}$ k & - & $5.8 \times 10^{3}$ & $8.0 \times 10^{-6}$ & - & {$[67]$} \\
\hline $\mathrm{Ni}(\mathrm{OH})_{2}-\mathrm{MnO}_{2}$ & - & - & - & 1.23 & [68] \\
\hline $\mathrm{Ni}(\mathrm{II})-$ SalenA/CPE & 0.087 & $1.03 \times 10^{5}$ & $1.18 \times 10^{-7}$ & 1.53 & This work \\
\hline
\end{tabular}

a MOF/GCE: Metal-organic framework/glassy carbon electrode.

b CuNPs-PANI-Nano-ZSM-5: Copper nanoparticles-polyaniline-ZSM-5 nanozeolite.

c G/NiCuCo: Graphite/nickel copper cobalt ternary alloy.

d NPA-NiCuP: Nanoporous nickel copper phosphorous amorphous alloy.

e $\mathrm{MBCPE} / \mathrm{Fe}_{3} \mathrm{O}_{4} \mathrm{NPs} / \mathrm{DPB}$ : Magnetic bar carbon paste electrode/ $\mathrm{Fe}_{3} \mathrm{O}_{4}$ magnetic nanoparticles/2-(3,4-dihydroxyphenyl)benzothiazole.

${ }^{\mathrm{f}} \mathrm{DBC}$-IL/CNPE: Benzofuran derivative-ionic liquids/carbon nanotube paste electrode.

g Ni(II)-BA-MWCNT-PE: Nickel(II)-baicalein-multiwall carbon nanotube-paste electrode.

h Co(II)BBAEDI-MWCNT-MCPE: Cobalt(II) bis(benzoylacetone)ethylenediimino-multiwall carbon nanotube-modified carbon paste electrode.

k NiPCNF: Ni-pentacyanonitrosylferrate.

${ }^{1}$ RGSs/GCE: Reduced graphene sheets modified glassy carbon electrode.

${ }^{\mathrm{m}} E_{p}(\mathrm{RHE})=E_{p}(\mathrm{Ag} \mid \mathrm{AgCl} / \mathrm{KCl}(3 \mathrm{~mol} / \mathrm{L}))+0.197+0.0591 \mathrm{pH}$.

the diffusion coefficient of $\mathrm{N}_{2} \mathrm{H}_{4}$. The charge response under diffusion control is described by the following equation [52]:

$$
Q=2 n F A c D^{1 / 2} \pi^{-1 / 2} t^{1 / 2}
$$

Fig. 10(b) displays experimental plots of $Q$ vs. $t^{1 / 2}$ for all concentrations of $\mathrm{N}_{2} \mathrm{H}_{4}$ (5-60 mmol/L) at the surface of $\mathrm{Ni}(\mathrm{II})-$ SalenA/CPE. In the next step, the slopes of the resulting straight lines were plotted against $\mathrm{N}_{2} \mathrm{H}_{4}$ concentration (Fig. $10(\mathrm{c})$ ). From the slope of the resulting plot and using Eq. (9), the mean value of $D$ was determined to be $1.27 \times 10^{-7} \mathrm{~cm}^{2} / \mathrm{s}$ in the range of $5.0-60.0 \mathrm{mmol} / \mathrm{L} \mathrm{N}_{2} \mathrm{H}_{4}$, which is similar to the $D$ value obtained from double-step chronoamperometry.

\subsection{Repeatability, reproducibility, and stability of Ni(II)SalenA/CPE}

For a novel electrode, long-term stability is an important parameter. The reproducibility and stability of $\mathrm{Ni}(\mathrm{II})$-SalenA/CPE were evaluated via the comparison of the currents of five different electrodes containing $15 \%$ $\mathrm{Ni}(\mathrm{II})$-SalenA using the $\mathrm{CV}$ technique. The anodic current of these electrodes in the presence of $20 \mathrm{mmol} / \mathrm{L} \mathrm{N}_{2} \mathrm{H}_{4}$ was tested independently and the RSD\% was $3.75 \%$. A reproducible current response with an RSD of 3.08\% was observed for five successive assays at $20 \mathrm{mmol} / \mathrm{L} \mathrm{N}_{2} \mathrm{H}_{4}$. The long-term stability was explored by measuring a $\mathrm{N}_{2} \mathrm{H}_{4}$ solution intermittently, with the electrode stored at room temperature when not in use. After 1 and 3 months, the electrode response to electrocatalytic oxidation of $\mathrm{N}_{2} \mathrm{H}_{4}$ retained about $95 \%$ and $88 \%$ of the initial value, respectively.

In order to investigate the long-term stability of $\mathrm{Ni}(\mathrm{II})-$ SalenA/CPE, this electrode was subjected to 50 cycles between 0.0 and $0.9 \mathrm{~V}$ at a scan rate of $100 \mathrm{mV} / \mathrm{s}$ in $0.1 \mathrm{~mol} / \mathrm{L}$ $\mathrm{NaOH}$ solution (Fig. S5(a)). The electrode retained $98.7 \%$ of its initial current response after 50 cycles and no significant change was detected in the peak potential values. These results indicate mechanical and chemical stability as well as a reproducible response of $\mathrm{Ni}(\mathrm{II})$-SalenA/CPE in the absence of $\mathrm{N}_{2} \mathrm{H}_{4}$. The stability of Ni(II)-SalenA/CPE was also evaluated in 0.1 mol/L $\mathrm{NaOH}$ solution containing $10.0 \mathrm{mmol} / \mathrm{L} \mathrm{N}_{2} \mathrm{H}_{4}$ (Fig. S5(b)). After 50 repetitive cycles, the electrode retained about $79.5 \%$ of its initial anodic current response with no significant alteration in the peak potential value, which indicates long-term stability of the modified electrode toward $\mathrm{N}_{2} \mathrm{H}_{4}$ electrooxidation. This decrease in the current response can be attributed to a small leak of nickel species into the solution and/or slight contamination of the active sites by the adsorption of $\mathrm{N}_{2} \mathrm{H}_{4}$ oxidation products, such as $\mathrm{N}_{2}$ gas [49].

For further evaluation of the electrocatalytic activity and long-term stability of the catalysts, chronoamperograms were recorded for $\mathrm{Ni}(\mathrm{II})-$ SalenA/CPE at a peak potential of $0.65 \mathrm{~V}$ in 

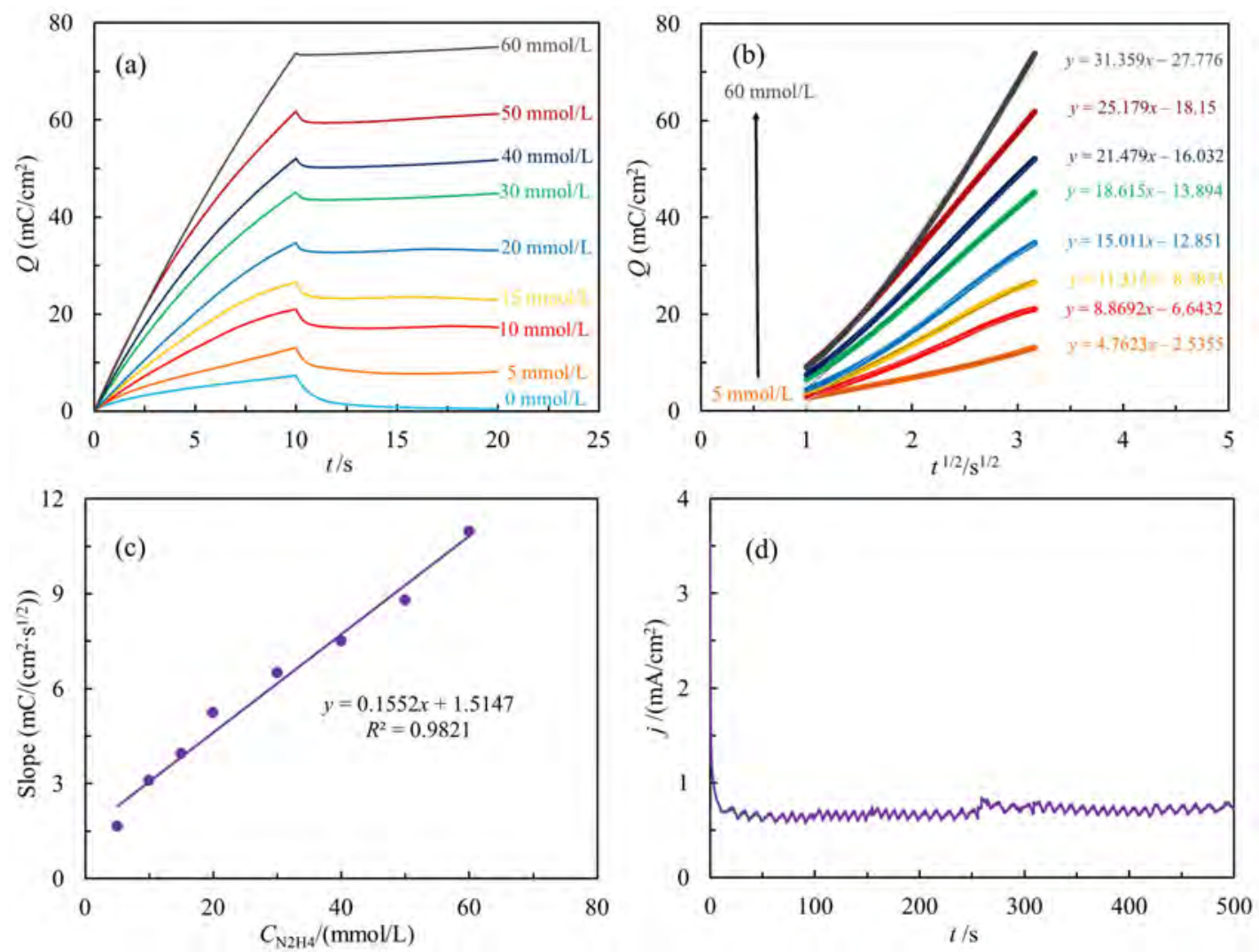

Fig. 10. (a) Chronocoulomograms of $\mathrm{Ni}(\mathrm{II})-\mathrm{SalenA} / \mathrm{CPE}$ in $0.1 \mathrm{~mol} / \mathrm{L} \mathrm{NaOH}$ solution in the absence and presence of different concentrations of $\mathrm{N}_{2} \mathrm{H}_{4}$. The potential steps were 0.65 and $0.30 \mathrm{~V}$ vs. $\mathrm{Ag}|\mathrm{AgCl}| \mathrm{KCl}\left(3 \mathrm{~mol} / \mathrm{L}\right.$ ). (b) Dependence of $Q$ on $t^{1 / 2}$ at each concentration of $\mathrm{N}_{2} \mathrm{H}_{4}$. (c) Plot of the slopes of the straight lines vs. $\mathrm{N}_{2} \mathrm{H}_{4}$ concentration. (d) Current-time transient for oxidation of $10 \mathrm{mmol} / \mathrm{L} \mathrm{N} \mathrm{H}_{4}$ on the surface of Ni(II)-SalenA/CPE in $0.1 \mathrm{~mol} / \mathrm{L}$ $\mathrm{NaOH}$ solution at a potential step of $0.65 \mathrm{~V}$ vs. $\mathrm{Ag}|\mathrm{AgCl}| \mathrm{KCl}(3 \mathrm{~mol} / \mathrm{L})$.

$0.1 \mathrm{~mol} / \mathrm{L} \mathrm{NaOH}$ solution containing $10 \mathrm{mmol} / \mathrm{L} \mathrm{N}_{2} \mathrm{H}_{4}$ (Fig. $10(d)$ ). As can be seen in this figure, the decrease in current density at initial times is relatively large. However, when the time is greater than $25 \mathrm{~s}$, the current density reaches a relatively stable value. Fluctuations in current during continuous operation may be due to the generation of $\mathrm{N}_{2}$ gas bubbles on the catalytic active sites of $\mathrm{Ni}(\mathrm{II})$-SalenA/CPE. It is obvious that this electrode exhibits good stability toward $\mathrm{N}_{2} \mathrm{H}_{4}$ oxidation [13]. In addition, Ni(II)-SalenA remained stable in the structure of the fabricated electrode in $0.1 \mathrm{~mol} / \mathrm{L} \mathrm{NaOH}$ solution.

\section{Conclusions}

In this study, organic-template-free synthesis of nanozeolite LTA was performed. A new nanozeolite-encapsulated catalyst (Ni(II)-SalenA) was successfully prepared using the flexible ligand method and then this catalyst was used for the modification of a CPE. The experimental results revealed that $\mathrm{Ni}(\mathrm{II})-$ SalenA/CPE has good electrochemical stability, reproducibility, and electrocatalytic activity in $0.1 \mathrm{~mol} / \mathrm{L} \mathrm{NaOH}$ solution. Ni(II)-SalenA/CPE showed higher catalytic performance for the electrocatalytic oxidation of $\mathrm{N}_{2} \mathrm{H}_{4}$ than other electrodes in this work and some in previous studies. The porous structure of nanozeolite LTA provides a framework for $\mathrm{Ni}^{2+}$ uptake and encapsulation of salen ligands in nanozeolite supercages, which are converted to $\mathrm{Ni}(\mathrm{OH})_{2}$ and $\mathrm{NiOOH}$ during anodic oxi- dation in alkaline solution and participate in the electrooxidation of $\mathrm{N}_{2} \mathrm{H}_{4}$. The effects of potential scan rate and $\mathrm{N}_{2} \mathrm{H}_{4}$ concentration were considered, and the results showed that oxidation of $\mathrm{N}_{2} \mathrm{H}_{4}$ on $\mathrm{Ni}(\mathrm{II})$-SalenA/CPE in $0.1 \mathrm{~mol} / \mathrm{L} \mathrm{NaOH}$ solution was a diffusion-controlled electrocatalytic process in a wide potential range, which proceeds via an EC' mechanism. The diffusion coefficient and the catalytic rate constant for $\mathrm{N}_{2} \mathrm{H}_{4}$ electrooxidation were determined using chronoamperometric and chronocoulometric methods. In addition, the general reaction mechanism for the electrooxidation of $\mathrm{N}_{2} \mathrm{H}_{4}$ on the surface of Ni(II)-SalenA/CPE in alkaline solution was established to involve a one-electron-transfer reaction as the rate-limiting step followed by a three-electron process to produce environmentally friendly nitrogen and water as final products.

\section{References}

[1] G. Dutta, S. Nagarajan, L. J. Lapidus, P. B. Lillehoj, Biosensors Bioelectron., 2017, 92, 372-377.

[2] H. Hosseini, H. Ahmar, A. Dehghani, A. Bagheri, A. R. Fakhari, M. M. Amini, Electrochim. Acta, 2013, 88, 301-309.

[3] A. Senthil Kumar, P. Barathi, K. Chandrasekara Pillai, J. Electroanal. Chem., 2011, 654, 85-95.

[4] R. Gupta, P. K. Rastogi, V. Ganesan, D. K. Yadav, P. K. Sonkar, Sensors Actuat. B, 2017, 239, 970-978.

[5] R. Liu, X. Jiang, F. Guo, N. N. Shi, J. L. Yin, G. L. Wang, D. X. Cao, Electrochim. Acta, 2013, 94, 214-218. 


\section{Graphical Abstract}

Chin. J. Catal., 2018, 39: 283-296 doi: 10.1016/S1872-2067(18)63025-6

Encapsulation of a nickel salen complex in nanozeolite LTA as a carbon paste electrode modifier for electrocatalytic oxidation of hydrazine

Seyed Karim Hassaninejad-Darzi *

Babol Noshirvani University of Technology, Iran

Ni(II)-SalenA/CPE for Electro-catalytic oxidation of Hydrazine
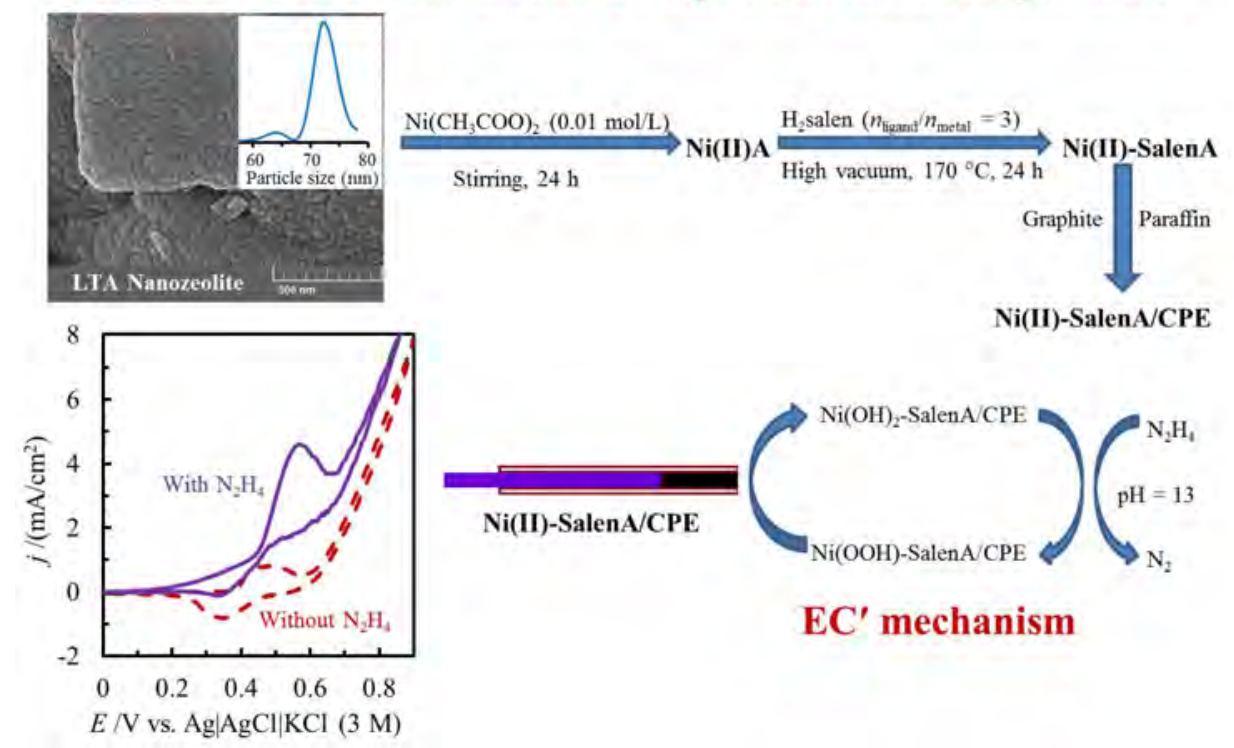

$\mathrm{Ni(II)-SalenA/CPE}$

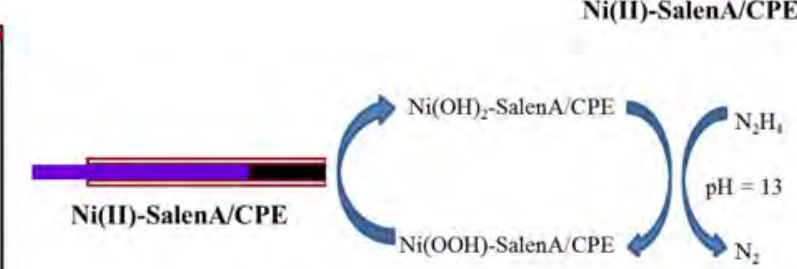

\section{EC' mechanism}

Organic template free synthesis of nanozeolite NaA, LTA (Linde Type A) structure, was performed and nickel salen complex was encapsulated in the supercages of the nanozeolite NaA using the flexible ligand method. The prepared Ni(II)-SalenA was used for modification of CPE to obtain Ni(II)-SalenA/CPE. This modified electrode was applied for electro-catalytic oxidation of hydrazine in alkaline medium.

[6] K. I. Ozoemena, T. Nyokong, Talanta, 2005, 67, 162-168.

[7] B. Kaur, R. Srivastava, B. Satpati, Cataly. Sci. Technol., 2016, 6, 1134-1145.

[8] Y. Liang, K. Wu, C. Ge, Y. Zhou, Y. Chen, Y. Tang, T. Lu, Fuel Cells, 2012, 12, 946-955.

[9] D. M. Zhang, B. Wang, D. X. Cao, K. Ye, Y. Xu, J. L. Yin, K. Cheng, G. L. Wang, Mater. Sci. Eng. B, 2014, 188, 48-53.

[10] M. Jafarian, T. Rostami, M. G. Mahjani, F. Gobal, J. Electroanal. Chem., 2016, 763, 134-140.

[11] X. L. Wang, Y. X. Zheng, M. L. Jia, L. S. Yuan, C. Peng, W. H. Yang, Int. J. Hydrogen Energy, 2016, 41, 8449-8458.

[12] D. C. de Oliveira, W. O. Silva, M. Chatenet, F. H. Lima, Appl. Catal. B, 2017, 201, 22-28.

[13] S. R. Hosseini, S. Ghasemi, M. Kamali-Rousta, J. Power Sources, 2017, 343, 467-476.

[14] A. A. Ensafi, M. Lotfi, H. Karimi-Maleh, Chin. J. Catal., 2012, 33, 487-493.

[15] H. R. Zare, N. Nasirizadeh, Electroanalysis, 2006, 18, 507-512.

[16] S. V. Guerra, L. T. Kubota, C. R. Xavier, S. Nakagaki, Anal. Sci., 1999, $15,1231-1234$.

[17] A. Benvidi, S. Jahanbani, B. F. Mirjalili, R. Zare, Chin. J. Catal., 2016, 37, 549-560.

[18] D. R. Rolison, Chem. Rev., 1990, 90, 867-878.

[19] X. D. Liu, Y. P. Wang, X. M. Cui, Y. He, J. Mao, Powder Technol., 2013, 243, 184-193.

[20] S. K. Hassaninejad-Darzi, M. Rahimnejad, S. N. Mirzababaei, Mi- crochem. J., 2016, 128, 7-17.

[21] B. Bayati, A. A. Babaluo, R. Karimi, J. Eur. Ceram. Soc., 2008, 28, 2653-2657.

[22] A. Walcarius, Chem. Soc. Rev., 2013, 42, 4098-4140.

[23] X. F. Guo, G. J. Kim, Top. Catal., 2010, 53, 510-516.

[24] G. J. Kim, S. H. Kim, Catal. Lett., 1999, 57, 139-143.

[25] W. Y. Wang, R. F. Li, R. Zhang, J. L. Ma, B. C. Wang, J. Electroanal. Chem., 2015, 742, 110-121.

[26] W. Y. Wang, R. F. Li, L. Liu, R. Zhang, B. C. Wang, J. Solid State Electrochem., 2015, 19, 2001-2012.

[27] W. Y. Wang, R. F. Li, X. Hua, R. Zhang, Electrochim. Acta, 2015, 163, 48-56.

[28] R. Zhang, W. K. Zhang, L. Z. Gao, J. Zhang, P. Li, W. Y. Wang, R. F. Li, Appl. Catal. A, 2013, 466, 264-271.

[29] X. Zhang, D. X. Tang, G. J. Jiang, Adv. Powder Technol., 2013, 24, 689-696.

[30] B. M. Daas, S. Ghosh, J. Electroanal. Chem., 2016, 783, 308-315.

[31] M. Salavati-Niasari, M. Shakouri-Arani, F. Davar, Microporous Mesoporous Mater., 2008, 116, 77-85.

[32] S. Brunauer, P. H. Emmett, E. Teller, J. Am. Chem. Soc., 1938, 60, 309-319.

[33] M. M. J. Treacy, J. B. Higgins, Collection of Simulated XRD Powder Patterns for Zeolites, 5th Ed., Elsevier, 2007.

[34] N. B. Castagnola, P. K. Dutta, J. Phys. Chem. B, 1998, 102, 1696-1702.

[35] B. Z. Zhan, M. A. White, M. Lumsden, J. Mueller-Neuhaus, K. N. 
Robertson, T. S. Cameron, M. Gharghouri, Chem. Mater., 2002, 14, 3636-3642.

[36] A. Nezamzadeh-Ejhieh, M. Karimi-Shamsabadi, Chem. Eng. J., 2013, 228, 631-641.

[37] B. B. Fan, H. Y. Li, W. B. Fan, C. Jin, R. F. Li, Appl. Catal. A, 2008, 340, 67-75.

[38] S. Storck, H. Bretinger, W. F. Maier, Appl. Catal. A, 1998, 174, 137-146.

[39] K. S. Sing, D. H. Evertt, R. A. W. Haul, L. Moscou, R. A. Pierotti, J. Rouquerol, T. Siemieniwwska, Pure Appl. Chem., 1985, 57, 603-619.

[40] Z. T. Xue, J. H. Ma, W. M. Hao, X. Bai, Y. H. Kang, J. H. Liu, R. F. Li, J. Mater. Chem., 2012, 22, 2532-2538.

[41] J. Rouquerol, D. Avnir, C. W. Fairbridge, D. H. Everett, J. H. Haynes, N. Pernicone, J. D. F. Ramsay, K. S. W. Sing, K. K. Unger, Pure Appl. Chem., 1994, 66, 1739-1758.

[42] E. R. Shilpa, V. Gayathri, J. Environ. Chem. Eng., 2016, 4, 4194-4206.

[43] S. K. Hassaninejad-Darzi, RSC Adv., 2015, 5, 105707-105718.

[44] S. K. Hassaninejad-Darzi, M. Gholami-Esfidvajani, Int. J. Hydrogen Energy, 2016, 41, 20085-20099.

[45] R. Ojani, J. B. Raoof, S. R. H. Zavvarmahalleh, Electrochim. Acta, 2008, 53, 2402-2407.

[46] A. A. El-Shafei, A. M. Abd Elhafeez, H. A. Mostafa, J. Solid State Electrochem., 2010, 14, 185-190.

[47] M. Fleischmann, K. Korinek, D. Pletcher, J. Electroanal. Chem. Interf. Electrochem., 1971, 31, 39-49.

[48] S. N. Azizi, S. Ghasemi, H. Yazdani-Sheldarrei, Int. J. Hydrogen Energy, 2013, 38, 12774-12785.

[49] A. Samadi-Maybodi, S. Ghasemi, H. Ghaffari-Rad, J. Power Sources, 2016, 303, 379-387.

[50] E. Laviron, J. Electroanal. Chem. Interf. Electrochem., 1979, 101, 19-28.
[51] S. K. Hassaninejad-Darzi, J. Electroceram., 2014, 33, 252-263.

[52] A. J. Bard, L. R. Faulkner, Electrochemical Methods, 2nd ed., Wiley, New York, 2001.

[53] B. Habibi, N. Delnavaz, Int. J. Hydrogen Energy, 2010, 35, 8831-8840.

[54] F. I. Miao, B. R. Tao, L. Sun, T. Liu, J. C. You, L. W. Wang, P. K. Chu, J. Power Sources, 2010, 195, 146-150.

[55] S. J. R. Prabakar, S. S. Narayanan, J. Electroanal. Chem., 2008, 617, 111-120.

[56] I. Danaee, M. Jafarian, F. Forouzandeh, F. Gobal, M. G. Mahjani, Int. J. Hydrogen Energy, 2008, 33, 4367-4376.

[57] D. K. Gosser, Cyclic Voltammetry: Simulation and Analysis of Reaction Mechanisms, VCH, New York, 1993.

[58] M. Hosseini, M. M. Momeni, M. Faraji, J. Mol. Catal. A, 2011, 335, 199-204.

[59] H. X. Luo, Z. J. Shi, N. Q. Li, Z. N. Gu, Q. K. Zhuang, Anal. Chem., 2001, 73, 915-920.

[60] L. Zheng, J. F. Song, Talanta, 2009, 79, 319-326.

[61] Y. Wang, Y. Wan, D. Zhang, Electrochem. Commun., 2010, 12, 187-190.

[62] R. Zhang, L. Liu, Y. H. Li, W. Y. Wang, R. F. Li, Int. J. Electrochem. Sci, 2015, 10, 2355-2369.

[63] M. Mazloum-Ardakani, A. Khoshroo, Electrochim. Acta, 2013, 103, 77-84.

[64] A. Benvidi, P. Kakoolaki, H. R. Zare, R. Vafazadeh, Electrochim. Acta, 2011, 56, 2045-2050.

[65] M. M. Ardakani, P. E. Rahimi, H. R. Zare, H. Naeimi, Electrochim. Acta, 2007, 52, 6118-6124.

[66] U. P. Azad, V. Ganesan, Electrochim. Acta, 2011, 56, 5766-5770.

[67] H. Razmi-Nerbin, M. H. Pournaghi-Azar, J. Solid State Electrochem., 2002, 6, 126-133.

[68] M. U. Anu Prathap, V. Anuraj, B. Satpati, R. Srivastava, J. Hazard. Mater., 2013, 262, 766-774.

\title{
纳米分子篮LTA包裹Ni-Salen配合物为修饰碳糊电极用于电催化氧化肼反应
}

\author{
Seyed Karim Hassaninejad-Darzi ${ }^{*}$ \\ Babol Noshirvani科技大学基础科学院化学系, 巴博勒47148-71167, 伊朗
}

摘要: 采用柔性配体法将Ni-salen配合物包裹在纳米分子篎LTA的超笼中, 用来修饰碳糊电极制得Ni(II)-SalenA/CPE, 并采 用循环伏安法、计时电流法和计时库仑法考察了该电极电催化氧化 $0.1 \mathrm{~mol} / \mathrm{L} \mathrm{NaOH}$ 溶液中肼反应性能. 首先采用无有机模 板剂法合成纳米分子篮LTA, 并用各种技术进行了表征. XRD和粒径分析结果分别显示LTA晶体的平均粒径为 56.1 和 $72 \mathrm{~nm}$. 在 $\mathrm{Ni}(\mathrm{II})-\mathrm{SalenA} / \mathrm{CPE}$ 电极氧化还原位上水合肼催化氧化反应电子转移系数为 0.64 , 速率常数为 $1.03 \times 10^{5} \mathrm{~cm}^{3} /(\mathrm{mol} \cdot \mathrm{s})$. 电催化反应机理研究表明, 水合肼氧化反应通过它与 $\mathrm{Ni}^{3+}(\mathrm{Salen}) \mathrm{O}(\mathrm{OH})$ 反应或直接进行电氧化反应. 阳极峰电流与扫描速 率的平方根呈线性关系, 表明反应受扩散控制, 水合肼的扩散系数为 $1.18 \times 10^{-7} \mathrm{~cm}^{2} / \mathrm{s}$. 结果表明, Ni(II)-SalenA/CPE对水合 肼氧化反应表现出高的电催化活性, 这是由于纳米分子笁LTA的多孔结构以及 $\mathrm{Ni}(\mathrm{II})-\mathrm{Salen}$ 的存在. 最后研究了水合肼在碱 性溶液中 $\mathrm{Ni}$ (II)-SalenA/CPE电极上的氧化反应机理, 发现其为四电子过程, 第一个电子转移反应为速率控制步骤, 然后是一 个三电子过程, 产生环境友好的最终产物氮气和水.

关键词: 纳米分子篎LTA; Salen配合物; $\mathrm{Ni}(\mathrm{II})-\mathrm{SalenA} / \mathrm{CPE}$; 肼; 电催化氧化; 燃料电池

收稿日期: 2017-09-26. 接受日期: 2018-01-14. 出版日期: 2018-02-05.

*通讯联系人. 电话: +981-132332071-1735; 传真: +981-132334203; 电子信箱: hassaninejad@nit.ac.ir

本文的电子版全文由Elsevier出版社在ScienceDirect上出版(http://www.sciencedirect.com/science/journal/18722067). 